\title{
The contribution of oceanic methyl iodide to stratospheric iodine
}

\author{
S. Tegtmeier ${ }^{1}$, K. Krüger ${ }^{1, *}$, B. Quack ${ }^{1}$, E. Atlas ${ }^{2}$, D. R. Blake ${ }^{3}$, H. Boenisch ${ }^{4}$, A. Engel $^{4}$, H. Hepach ${ }^{1}$, R. Hossaini ${ }^{5}$, \\ M. A. Navarro ${ }^{2}$, S. Raimund ${ }^{1}$, S. Sala ${ }^{4}$, Q. Shi ${ }^{1}$, and F. Ziska ${ }^{1}$ \\ ${ }^{1}$ GEOMAR Helmholtz Centre for Ocean Research Kiel, Kiel, Germany \\ ${ }^{2}$ Rosenstiel School of Marine and Atmospheric Science, University of Miami, Miami, Florida, USA \\ ${ }^{3}$ University of California, Irvine, USA \\ ${ }^{4}$ Goethe University Frankfurt am Main, Frankfurt, Germany \\ ${ }^{5}$ Institute for Climate and Atmospheric Science, School of Earth and Environment, University of Leeds, Leeds, UK \\ *now at: University of Oslo, Oslo, Norway
}

Correspondence to: S. Tegtmeier (stegtmeier@geomar.de)

Received: 4 April 2013 - Published in Atmos. Chem. Phys. Discuss.: 30 April 2013

Revised: 14 October 2013 - Accepted: 6 November 2013 - Published: 9 December 2013

\begin{abstract}
We investigate the contribution of oceanic methyl iodide $\left(\mathrm{CH}_{3} \mathrm{I}\right)$ to the stratospheric iodine budget. Based on $\mathrm{CH}_{3} \mathrm{I}$ measurements from three tropical ship campaigns and the Lagrangian transport model FLEXPART, we provide a detailed analysis of $\mathrm{CH}_{3} \mathrm{I}$ transport from the ocean surface to the cold point in the upper tropical tropopause layer (TTL). While average oceanic emissions differ by less than $50 \%$ from campaign to campaign, the measurements show much stronger variations within each campaign. A positive correlation between the oceanic $\mathrm{CH}_{3} \mathrm{I}$ emissions and the efficiency of $\mathrm{CH}_{3} \mathrm{I}$ troposphere-stratosphere transport has been identified for some cruise sections. The mechanism of strong horizontal surface winds triggering large emissions on the one hand and being associated with tropical convective systems, such as developing typhoons, on the other hand, could explain the identified correlations. As a result of the simultaneous occurrence of large $\mathrm{CH}_{3} \mathrm{I}$ emissions and strong vertical uplift, localized maximum mixing ratios of $0.6 \mathrm{ppt} \mathrm{CH}_{3} \mathrm{I}$ at the cold point have been determined for observed peak emissions during the SHIVA (Stratospheric Ozone: Halogen Impacts in a Varying Atmosphere)-Sonne research vessel campaign in the coastal western Pacific. The other two cam-

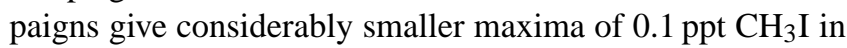
the open western Pacific and 0.03 ppt in the coastal eastern Atlantic. In order to assess the representativeness of the large local mixing ratios, we use climatological emission scenarios to derive global upper air estimates of $\mathrm{CH}_{3} \mathrm{I}$ abundances. The model results are compared with available upper air measurements, including data from the recent ATTREX and HIPPO2
\end{abstract}

aircraft campaigns. In the eastern Pacific region, the location of the available measurement campaigns in the upper TTL, the comparisons give a good agreement, indicating that around 0.01 to $0.02 \mathrm{ppt}$ of $\mathrm{CH}_{3} \mathrm{I}$ enter the stratosphere. However, other tropical regions that are subject to stronger convective activity show larger $\mathrm{CH}_{3} \mathrm{I}$ entrainment, e.g., $0.08 \mathrm{ppt}$ in the western Pacific. Overall our model results give a tropical contribution of $0.04 \mathrm{ppt} \mathrm{CH}_{3} \mathrm{I}$ to the stratospheric iodine budget. The strong variations in the geographical distribution of $\mathrm{CH}_{3} \mathrm{I}$ entrainment suggest that currently available upper air measurements are not representative of global estimates and further campaigns will be necessary in order to better understand the $\mathrm{CH}_{3} \mathrm{I}$ contribution to stratospheric iodine.

\section{Introduction}

It is currently believed that organic iodine compounds are not important for stratospheric ozone chemistry as a result of their very short lifetimes that allow only small fractions of the emitted iodine to reach the stratosphere (Aschmann et al., 2009; Montzka and Reimann, 2011). Emissions of iodinated compounds from the ocean into the atmosphere and subsequent strongly localized vertical transport in convective systems determines if and how much of the short-lived iodinated gases reach the upper tropical tropopause layer (TTL) and lower stratosphere. Both processes are highly variable in time and space and reliable global estimates should, if possible, be derived from frequent upper air observations and from model 
studies based on high resolution emission maps. In addition to the unknown variability of $\mathrm{CH}_{3} \mathrm{I}$ in the TTL, uncertainties in the knowledge of the atmospheric lifetime of inorganic iodine (e.g., Dix et al., 2013) pose a major challenge for the quantification of the stratospheric iodine budget. If iodinated species reach the upper troposphere and lower stratosphere (UTLS), they might enhance ozone destruction due to the possible role of active iodine in rapid interhalogen reactions (Solomon et al., 1994).

Methyl iodide $\left(\mathrm{CH}_{3} \mathrm{I}\right)$ is an important carrier of iodine from the surface to the free troposphere, where it plays an important role for ozone chemistry and oxidizing capacities (Chameides and Davis, 1980; Davis et al., 1996; McFiggans et al., 2000; O'Dowd et al., 2002; Saiz-Lopez et al., 2012; Vogt et al., 1999). $\mathrm{CH}_{3} \mathrm{I}$ is emitted mainly from the ocean where biological sources in form of algae and phytoplankton (e.g., Hughes et al., 2011; Manley and Dastoor, 1987, 1988; Manley and de la Cuesta, 1997; Smythe-Wright et al., 2006) and non-biological sources in form of photochemical production (e.g., Butler et al., 2007; Chuck et al., 2005; Happell and Wallace, 1996; Moore and Zafiriou, 1994; Richter and Wallace, 2004; Yokouchi et al., 2008) have been identified. Note that current studies suggest that organic sources of iodine cannot explain iodine oxide concentrations in the lower troposphere over the tropical oceans (Jones et al., 2010; Mahajan et al., 2010) and that emissions of inorganic iodine following heterogeneous reactions at the ocean surface can account for a primary source of oceanic iodine emissions (Carpenter et al., 2013).

Global emission estimates are based on oceanic and atmospheric $\mathrm{CH}_{3} \mathrm{I}$ concentrations obtained during ship cruises (bottom-up) and on model studies which are adjusted to $\mathrm{CH}_{3} \mathrm{I}$ upper-air observations (top-down) (Montzka and Reimann, 2011). Oceanic and atmospheric surface $\mathrm{CH}_{3} \mathrm{I}$ is characterized by a large spatial (e.g., Ziska et al., 2013) and temporal (e.g., Fuhlbrügge et al., 2013) variability. Additionally, differences between calibration scales, applied during past campaigns, might exist (Butler et al., 2007). Estimating local fluxes from observations and extrapolating them to a larger scale in order to derive global estimates may thus result in large uncertainties. Atmospheric modeling studies, on the other hand, prescribe global emissions with the emission strength chosen so as to reproduce atmospheric aircraft observations and might miss the importance of localized sources. As a result, emissions are poorly constrained and available global oceanic flux estimates based on the different approaches (top-down, bottom-up and laboratory experiments) range widely from 180 to $1163 \mathrm{Gg} \mathrm{Iyr}^{-1}$. An overview of available global oceanic emission estimates in the literature is given in Table $1 \mathrm{in} \mathrm{Gg} \mathrm{I} \mathrm{yr}^{-1}$ and, for a better comparability with the ship campaign emissions presented in Sect. 3, in pmol $\mathrm{CH}_{3} \mathrm{Im}^{-2} \mathrm{~h}^{-1}$. Additionally, terrestrial sources such as rice paddies, wetlands, and biomass burning, which are not well quantified yet, are assumed to contribute
80-110 Gg I yr ${ }^{-1}$ (Bell et al., 2002; Redeker et al., 2000; Sive et al., 2007).

Atmospheric mixing ratios of $\mathrm{CH}_{3} \mathrm{I}$ in the marine boundary layer have been reported by a large number of measurement campaigns, and background values range between 0.4 and $1.6 \mathrm{ppt}$ (Saiz-Lopez et al., 2012 and references therein). With increasing altitude the $\mathrm{CH}_{3} \mathrm{I}$ abundance decreases and measurements from two aircraft campaigns reveal very little $\mathrm{CH}_{3} \mathrm{I}$ in the TTL, with mean values of $0.01 \mathrm{ppt}$ above $14 \mathrm{~km}$ (Montzka and Reimann, 2011). The two campaigns were conducted with the NASA WB57 high-altitude aircraft over Central America and the Gulf of Mexico, but due to the horizontal limitations of the campaign area, the results might not be representative of global $\mathrm{CH}_{3} \mathrm{I}$ estimates in the TTL. The observational data obtained during the aircraft campaigns, combined with the outcome of model studies (Aschmann et al., 2009; Donner et al., 2007; Gettelman et al., 2009), lead to the conclusion that no more than $0.05 \mathrm{ppt}$ of iodine enters the stratosphere in the form of the source gas $\mathrm{CH}_{3} \mathrm{I}$ (Montzka and Reimann, 2011). If $\mathrm{CH}_{3} \mathrm{I}$ is photolyzed before reaching the stratosphere, the generated inorganic iodine can be removed from the atmosphere by washout. It has been suggested recently that heterogeneous recycling of inorganic iodine on aerosol surfaces can occur (Dix et al., 2013), which could enable a longer atmospheric lifetime and possibly the direct entrainment of inorganic iodine into the stratosphere.

Once in the lower stratosphere, $\mathrm{CH}_{3} \mathrm{I}$ will contribute to the inorganic iodine $\left(\mathrm{I}_{\mathrm{y}}\right)$ budget, which is of interest due to the suggested efficiency of active iodine in destroying ozone (Davis et al., 1996; Solomon et al., 1994; WMO, 2007). Stratospheric iodine exists mostly in the form of free radicals (iodine atoms and iodine monoxide), so that the partitioning of free radicals to total halogen content is much higher for iodine than for chlorine or bromine (Brasseur and Solomon, 2005). Investigations of inorganic iodine species, in the form of iodine monoxide (IO) or iodine dioxide (OIO), in the lower stratosphere give an upper limit of IO of $0.3 \mathrm{ppt}$ based on ground-based measurements (Wennberg et al., 1997) and $0.2 \mathrm{ppt}$ based on solar-occultation balloon-borne measurements (Pundt et al., 1998). Other balloon campaigns in the upper TTL, however, detected no IO or OIO in the upper TTL above the detection limit at 0.1 ppt (Bösch et al., 2003; Butz et al., 2009). As a result, the total amount of stratospheric $\mathrm{I}_{\mathrm{y}}$ is currently estimated to be below $0.15 \mathrm{ppt}$ (Montzka and Reimann, 2011), arising from the detection limit of inorganic iodine $(0.1 \mathrm{ppt})$ given by the latter studies and the iodine supply in form of $\mathrm{CH}_{3} \mathrm{I}(0.05 \mathrm{ppt})$.

Due to its short lifetime of around 7 days (given in Montzka and Reimann, 2011), one expects $\mathrm{CH}_{3} \mathrm{I}$ in the troposphere and TTL to exhibit significantly large variability. The amount of $\mathrm{CH}_{3} \mathrm{I}$ transported from the ocean into the stratosphere is determined by oceanic emissions and the efficiency of atmospheric transport. In order to quantify the contribution of $\mathrm{CH}_{3} \mathrm{I}$ to the stratospheric $\mathrm{I}_{\mathrm{y}}$ budget, observations of $\mathrm{CH}_{3} \mathrm{I}$ and $\mathrm{IO}$ with a good global coverage would be 
Table 1. Global $\mathrm{CH}_{3} \mathrm{I}$ emission estimates in the literature given in $\mathrm{Gg} \mathrm{Iyr}^{-1}$ and additionally in pmol $\mathrm{CH}_{3} \mathrm{Im}^{-2} \mathrm{~h}^{-1}$.

\begin{tabular}{llll}
\hline $\begin{array}{l}\mathrm{CH}_{3} \mathrm{I} \text { emission } \\
\left(\mathrm{Gg} \mathrm{Iyr}^{-1}\right)\end{array}$ & $\begin{array}{l}\mathrm{CH}_{3} \mathrm{I} \text { emission } \\
\left(\mathrm{pmol} \mathrm{CH} \mathrm{I} \mathrm{m}^{-2} \mathrm{~h}^{-1}\right)\end{array}$ & Reference & Approach \\
\hline 241 & 593 & Liss and Slater (1974) & Bottom up \\
1163 & 2862 & Rasmussen et al. (1982) & Bottom up \\
$270-450$ & $665-1107$ & Singh et al. (1983) & Bottom up \\
134 & 330 & Campos et al. (1996) & Bottom-up \\
254 & 625 & Moore and Groszko (1999) & Bottom up \\
272 & 670 & Bell et al. (2002) & Bottom-up \\
180 & 443 & Chuck et al. (2005) & Bottom up \\
531 & 1307 & Smythe-Wright et al. (2006) & Lab-experiment \\
550 & 1354 & Butler et al. (2007) & Bottom-up \\
272 & 748 & Ordóñez et al. (2012) & Top-down \\
184 & 453 & Ziska et al. (2013) & Bottom-up \\
\hline
\end{tabular}

necessary. While in the UTLS such observational evidence of global iodine abundances does not exist so far, recent measurements in the free troposphere over the Canary Islands (Puentedura et al., 2012) and the Pacific Ocean (Dix et al., 2013) report significant amounts of IO of up to $0.4 \mathrm{ppt}$ and suggest that $\mathrm{IO}$ occurs in the lower troposphere on a global scale. At the surface, a variety of $\mathrm{CH}_{3} \mathrm{I}$ data originating from ship campaigns and the resulting first global emission climatology (Ziska et al., 2013) are available. Here, we use in situ $\mathrm{CH}_{3}$ I measurements from three tropical ship campaigns, one in the eastern Atlantic and two in the western Pacific, and a Lagrangian transport model to analyze the characteristics and the variability of $\mathrm{CH}_{3} \mathrm{I}$ transport from the ocean surface into the upper TTL. Furthermore, we derive upper air estimates of $\mathrm{CH}_{3} \mathrm{I}$ abundances based on the global emission climatology and compare them to available upper air measurements that include new data from various aircraft campaigns. The ship and aircraft campaigns as well as the atmospheric transport model are introduced in Sect. 2. Estimates of atmospheric $\mathrm{CH}_{3} \mathrm{I}$ abundances based on the individual ship campaigns are given in Sect. 3, while the model results based on global emissions, including their comparison to aircraft campaign data, are discussed in Sect. 4. We present the contribution of oceanic $\mathrm{CH}_{3} \mathrm{I}$ to stratospheric iodine in the form of the model estimated $\mathrm{CH}_{3} \mathrm{I}$ mixing ratios at the cold point. The summary and discussion of the key results can be found in Sect. 5 .

\section{Data and model}

\subsection{Ship campaigns}

Oceanic $\mathrm{CH}_{3} \mathrm{I}$ emissions from three tropical ship campaigns (Table 2), calculated from measurements of $\mathrm{CH}_{3} \mathrm{I}$ mixing ratios in the surface water and atmosphere, are used in this study. The two ship campaigns TransBrom-Sonne and SHIVA-Sonne took place in the open and coastal western Pacific while the DRIVE campaign was located in the north-

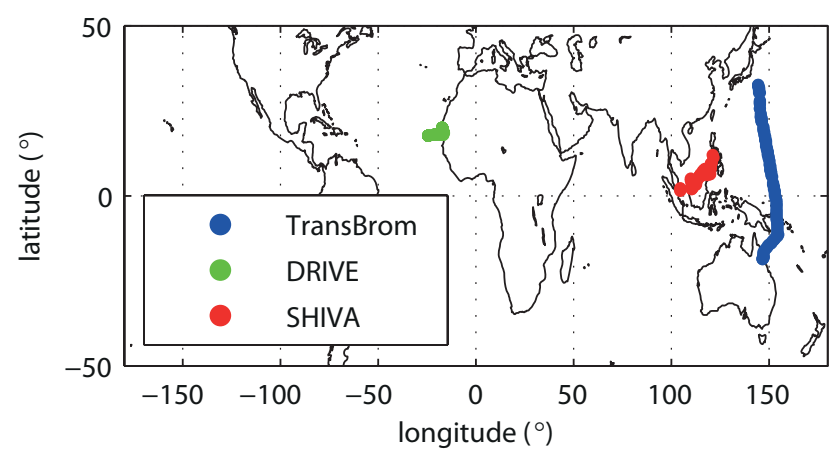

Fig. 1. Map of ship campaigns used in this study.

eastern Atlantic (Fig. 1). During each cruise, surface air samples were collected every 1 to $3 \mathrm{~h}$ in pressurized stainless steel canisters and analyzed subsequently for $\mathrm{CH}_{3} \mathrm{I}$ at the Rosenstiel School of Marine and Atmospheric Sciences (RSMAS) at the University of Miami by the group lead by Elliot Atlas. Surface water samples were collected simultaneously by a submersible pump at $5 \mathrm{~m}$ depth and analyzed on board using a purge-and-trap gas chromatography/mass spectrometry (GC/MS) analytical system (Quack et al., 2004). Both data sets were calibrated with a NOAA standard (Butler et al., 2007). The instantaneous $\mathrm{CH}_{3}$ I sea-to-air fluxes were calculated from the measured sea surface concentration and local atmospheric mixing ratios applying Henry's law constant from Moore et al. (1995) and the instantaneous $10 \mathrm{~min}$ average wind speed. Henry's law constant was calculated as a function of the $10 \mathrm{~min}$ average water temperature. The flux calculations are based on the transfer coefficient parameterization of Nightingale et al. (2000) adapted to $\mathrm{CH}_{3} \mathrm{I}$. For the parameterization, the transfer velocity at Schmidt number 660 , which corresponds to $\mathrm{CO}_{2}$ at $20^{\circ} \mathrm{C}$ in seawater (Wanninkhof, 1992), was corrected by the $\mathrm{CH}_{3}$ I Schmidt number at the temperature of measurement. The ratio of the diffusion coefficients from $\mathrm{CH}_{3} \mathrm{Br}$ (De Bruyn and Saltzman, 1997) and 
Table 2. Recent ship campaigns providing oceanic and atmospheric $\mathrm{CH}_{3} \mathrm{I}$ measurements.

\begin{tabular}{|c|c|c|c|c|}
\hline $\begin{array}{l}\text { Campaign } \\
(\mathrm{R} / \mathrm{V})\end{array}$ & Full name & Route & $\begin{array}{l}\text { Time } \\
\text { period }\end{array}$ & References \\
\hline $\begin{array}{l}\text { TransBrom- } \\
\text { Sonne } \\
\text { (Sonne) }\end{array}$ & $\begin{array}{l}\text { Very short lived bromine com- } \\
\text { pounds in the ocean and their } \\
\text { transport pathways into the } \\
\text { stratosphere - Sonne }\end{array}$ & $\begin{array}{l}\text { Western Pacific: } \\
\text { Tomakomai, Japan - } \\
\text { Townsville, Australia }\end{array}$ & $\begin{array}{l}2009 \\
\text { October }\end{array}$ & $\begin{array}{l}\text { Krüger and } \\
\text { Quack (2013) }\end{array}$ \\
\hline $\begin{array}{l}\text { DRIVE } \\
\text { (Poseidon) }\end{array}$ & $\begin{array}{l}\text { Diurnal and Regional } \\
\text { Variability of Halogen } \\
\text { Emissions }\end{array}$ & $\begin{array}{l}\text { Atlantic: } \\
\text { Las Palmas, Spain - } \\
\text { Vigo, Spain }\end{array}$ & $\begin{array}{l}2010 \\
\text { May/June }\end{array}$ & $\begin{array}{l}\text { Bange et al. } \\
\text { (2011) }\end{array}$ \\
\hline $\begin{array}{l}\text { SHIVA-Sonne } \\
\text { (Sonne) }\end{array}$ & $\begin{array}{l}\text { Stratospheric Ozone: Halogen } \\
\text { Impacts in a Varying } \\
\text { Atmosphere - Sonne }\end{array}$ & $\begin{array}{l}\text { Western Pacific: } \\
\text { Singapore - } \\
\text { Manila, Philippines }\end{array}$ & $\begin{array}{l}2011 \\
\text { November }\end{array}$ & $\begin{array}{l}\text { Quack and } \\
\text { Krüger (2013) }\end{array}$ \\
\hline
\end{tabular}

$\mathrm{CH}_{3} \mathrm{I}$, estimated according to Wilke and Chang (1955), was used as a function of temperature for the Schmidt-number correction (e.g., Richter and Wallace, 2004).

\subsection{Aircraft campaigns}

$\mathrm{CH}_{3} \mathrm{I}$ measurements in the upper troposphere and TTL are currently available from seven aircraft campaigns. Three campaigns provide data from the surface up to the upper troposphere/lower TTL: the TC4-DC8 over Central America and the HIPPO and SHIVA campaigns which took place in the Pacific and western Pacific area, respectively. Note that SHIVA is a combined aircraft-, ship- and ground-based campaign with measurements both from the ship and from the aircraft used in this study. From the HIPPO mission, we use here the measurements obtained during the HIPPO2 campaign in 2009. $\mathrm{CH}_{3} \mathrm{I}$ measurements in the upper TTL are available from Pre-AVE and TC4 campaigns. These two campaigns have been used to derive recent estimates of the upper air $\mathrm{CH}_{3} \mathrm{I}$ abundance (Montzka and Reimann, 2011). In addition to the data used for the current upper TTL $\mathrm{CH}_{3} \mathrm{I}$ estimate, observations from the ACCENT campaign in 1999 and from the ATTREX campaign in 2011 are included in our study. All four campaigns, which provide $\mathrm{CH}_{3} \mathrm{I}$ measurements in the upper TTL, took place over the southern US and Central America. Detailed information about the aircraft missions, including location and time period, are presented in Table 3.

\subsection{Global emission climatology}

The global emission scenario from Ziska et al. (2013) is a bottom-up estimate of the oceanic $\mathrm{CH}_{3} \mathrm{I}$ fluxes. Atmospheric and oceanic surface in situ measurements from the HalOcAt (Halocarbons in the ocean and atmosphere) database project (https://halocat.geomar.de) were used to generate global surface concentration maps. In a first step the surface measurements were classified based on physical and biogeochemi- cal characteristics of the ocean and atmosphere important for the $\mathrm{CH}_{3} \mathrm{I}$ distribution and sources. Within each classified region, the global $1^{\circ} \times 1^{\circ}$ grid was filled through the extrapolation of the in situ measurements based on the ordinary least square (OLS) regression technique. The estimated surface concentration maps do not provide any information on temporal variability, but represent climatological fields of a $20 \mathrm{yr}$ time period. Based on the global concentration maps, the oceanic emissions were calculated with the transfer coefficient parameterization of Nightingale et al. (2000), adapted to $\mathrm{CH}_{3} \mathrm{I}$. The emission parameterization is based on 6 hourly meteorological ERA-Interim data (Dee et al., 2011), taking into account emission peaks related to maxima in the horizontal wind fields. The final emission climatology product is calculated as the $20 \mathrm{yr}$-average emission field. Emission peaks related to 6 hourly wind maxima are not present any more in the final $20 \mathrm{yr}$ mean climatology; however, their existence in the temporally resolved emission fields counteracts a possible underestimation introduced by smoothing effects of the climatological approach.

\subsection{Modeling atmospheric transport}

The atmospheric transport of $\mathrm{CH}_{3} \mathrm{I}$ from the oceanic surface into the upper troposphere and TTL is simulated with the Lagrangian particle dispersion model, FLEXPART (Stohl et al., 2005). This model has been validated based on comparisons with measurement data from three large-scale tracer experiments (Stohl et al., 1998) and on intercontinental air pollution transport studies (e.g., Forster et al., 2001; Spichtinger et al., 2001; Stohl and Trickl, 1999). FLEXPART is driven by meteorological fields from the ECMWF (European Centre for Medium-Range Weather Forecasts) numerical weather prediction model and includes parameterizations for moist convection (Forster et al., 2007), turbulence in the boundary layer and free troposphere (Stohl and Thomson, 1999), dry 
Table 3. Aircraft campaigns with $\mathrm{CH}_{3} \mathrm{I}$ measurements used in the study.

\begin{tabular}{|c|c|c|c|c|c|}
\hline $\begin{array}{l}\text { Campaign } \\
\text { (Aircraft) }\end{array}$ & Full name & $\begin{array}{l}\text { Max. } \\
\text { altitude }\end{array}$ & Location & Time period & References \\
\hline $\begin{array}{l}\text { ACCENT } \\
(\text { WB57) }\end{array}$ & $\begin{array}{l}\text { Atmospheric Chemistry of } \\
\text { Combustion Emissions Near } \\
\text { the Tropopause }\end{array}$ & $19 \mathrm{~km}$ & $\begin{array}{l}\text { Southern US } \\
\text { Central America }\end{array}$ & $\begin{array}{l}1999 \\
\text { April, September }\end{array}$ & $\begin{array}{l}\text { http://espoarchive.nasa. } \\
\text { gov/archive/browse/ } \\
\text { accent }\end{array}$ \\
\hline $\begin{array}{l}\text { Pre-AVE } \\
\text { (WB57) }\end{array}$ & $\begin{array}{l}\text { Pre-Aura Validation } \\
\text { Experiment }\end{array}$ & $19 \mathrm{~km}$ & $\begin{array}{l}\text { Southern US } \\
\text { Central America }\end{array}$ & $\begin{array}{l}2004 \\
\text { January-February }\end{array}$ & $\begin{array}{l}\text { http://espoarchive.nasa. } \\
\text { gov/archive/browse/ } \\
\text { pre_ave }\end{array}$ \\
\hline $\begin{array}{l}\mathrm{TC} 4 \\
(\mathrm{DC} 8)\end{array}$ & $\begin{array}{l}\text { Tropical Composition, Cloud } \\
\text { and Climate Coupling }\end{array}$ & $12 \mathrm{~km}$ & $\begin{array}{l}\text { Southern US } \\
\text { Central America }\end{array}$ & $\begin{array}{l}2007 \\
\text { July-August }\end{array}$ & Toon et al. (2010) \\
\hline $\begin{array}{l}\text { TC4 } \\
\text { (WB57) }\end{array}$ & $\begin{array}{l}\text { Tropical Composition, Cloud } \\
\text { and Climate Coupling }\end{array}$ & $19 \mathrm{~km}$ & $\begin{array}{l}\text { Southern US } \\
\text { Central America }\end{array}$ & $\begin{array}{l}2007 \\
\text { August }\end{array}$ & Toon et al. (2010) \\
\hline $\begin{array}{l}\text { HIPPO2 } \\
\text { (HIAPER) }\end{array}$ & $\begin{array}{l}\text { HIAPER Pole-to-Pole } \\
\text { Observations } 2\end{array}$ & $14 \mathrm{~km}$ & Pacific & $\begin{array}{l}2009 \\
\text { November }\end{array}$ & Wofsy et al. (2011) \\
\hline $\begin{array}{l}\text { ATTREX } \\
\text { (Global } \\
\text { Hawk) }\end{array}$ & $\begin{array}{l}\text { Airborne Tropical Tropopause } \\
\text { Experiment }\end{array}$ & $19 \mathrm{~km}$ & Eastern Pacific & $\begin{array}{l}2011 \\
\text { October-November }\end{array}$ & $\begin{array}{l}\text { http://espo.nasa.gov/ } \\
\text { missions/attrex }\end{array}$ \\
\hline $\begin{array}{l}\text { SHIVA } \\
\text { (Falcon) }\end{array}$ & $\begin{array}{l}\text { Stratospheric ozone: Halogen } \\
\text { Impacts in a Varying } \\
\text { Atmosphere }\end{array}$ & $14 \mathrm{~km}$ & $\begin{array}{l}\text { Western Pacific } \\
\text { (Maritime } \\
\text { Continent) }\end{array}$ & $\begin{array}{l}2011 \\
\text { November }\end{array}$ & $\begin{array}{l}\text { http://shiva.iup. } \\
\text { uni-heidelberg.de/ } \\
\text { index.html }\end{array}$ \\
\hline
\end{tabular}

deposition and in-cloud as well as below-cloud scavenging, and the simulation of chemical decay.

We perform two different kinds of studies based on the different model setups, one using in situ emissions observed during individual ship campaigns and one using a global emission climatology. For the in situ experiments, the transport of $\mathrm{CH}_{3} \mathrm{I}$ is simulated with a multitude of trajectories launched for each emission data point, as described in detail by Tegtmeier et al. (2012). The trajectories are assigned the amounts of $\mathrm{CH}_{3} \mathrm{I}$ emitted from a $0.0002^{\circ} \times 0.0002^{\circ}$ grid box $\left(\sim 500 \mathrm{~m}^{2}\right)$ at the measurement location over one hour, as calculated from the observation-derived flux. Atmospheric mixing ratio profiles resulting from in situ emissions have been determined following the method described in Tegtmeier et al. (2012). The calculation of global $\mathrm{CH}_{3} \mathrm{I}$ estimates is based on the emission climatology from Ziska et al. (2013). The oceanic sea-to-air flux is given globally on a $1^{\circ} \times 1^{\circ}$ grid. From each grid box 10 trajectories are released per day, carrying the according amount of $\mathrm{CH}_{3} \mathrm{I}$ as prescribed by the emission scenario. While the simulations based on the in situ ship campaign data are carried out for the time period of the respective ship campaigns (see Table 2), the global simulations are run for the year 2009. Additionally, the global simulations are carried out for the time periods of the aircraft campaigns (see Table 3 ) in order to allow for a direct comparison between aircraft measurements and model results. The FLEXPART runs are driven by the ECMWF reanalysis product ERA-Interim (Dee et al., 2011), given at a horizontal resolution of $1^{\circ} \times 1^{\circ}$ on 60 model levels. Transport, dispersion and convection of the air parcels are calculated from the 6-hourly fields of horizontal and vertical wind, temperature, specific humidity, convective, and large scale precipitation and others. The vertical wind is calculated in hybrid coordinates mass consistently from spectral data by the preprocessor, which retrieves the meteorological fields from the ECMWF archives.

The atmospheric lifetime of $\mathrm{CH}_{3} \mathrm{I}$ was assumed to be constant in the troposphere and set to 7 days according to current estimates (Montzka and Reimann, 2011). Trajectories were terminated after 20 days. For a sensitivity study, an altitudedependent lifetime of $\mathrm{CH}_{3} \mathrm{I}$, derived by the TOMCAT chemical transport model (CTM) (Chipperfield, 2006), was also used. The CTM calculated tropospheric loss of $\mathrm{CH}_{3} \mathrm{I}$ through photolysis, the major tropospheric sink, using the recommended absorption cross section data of Sander et al. (2011). The modeled $\mathrm{CH}_{3} \mathrm{I}$ lifetime diagnosed by the CTM is relatively short $(\sim 2-3$ days $)$ in the tropical troposphere and thus this experiment is useful for examining the sensitivity of $\mathrm{CH}_{3}$ I loading in the upper troposphere to a range of lifetimes. Previously, $\mathrm{CH}_{3} \mathrm{I}$ profiles from TOMCAT have been shown to agree well with aircraft observations in the tropical troposphere (Hossaini et al., 2012). The mass of the $\mathrm{CH}_{3} \mathrm{I}$ carried by each air parcel is reduced at a rate corresponding to its chemical lifetime. 

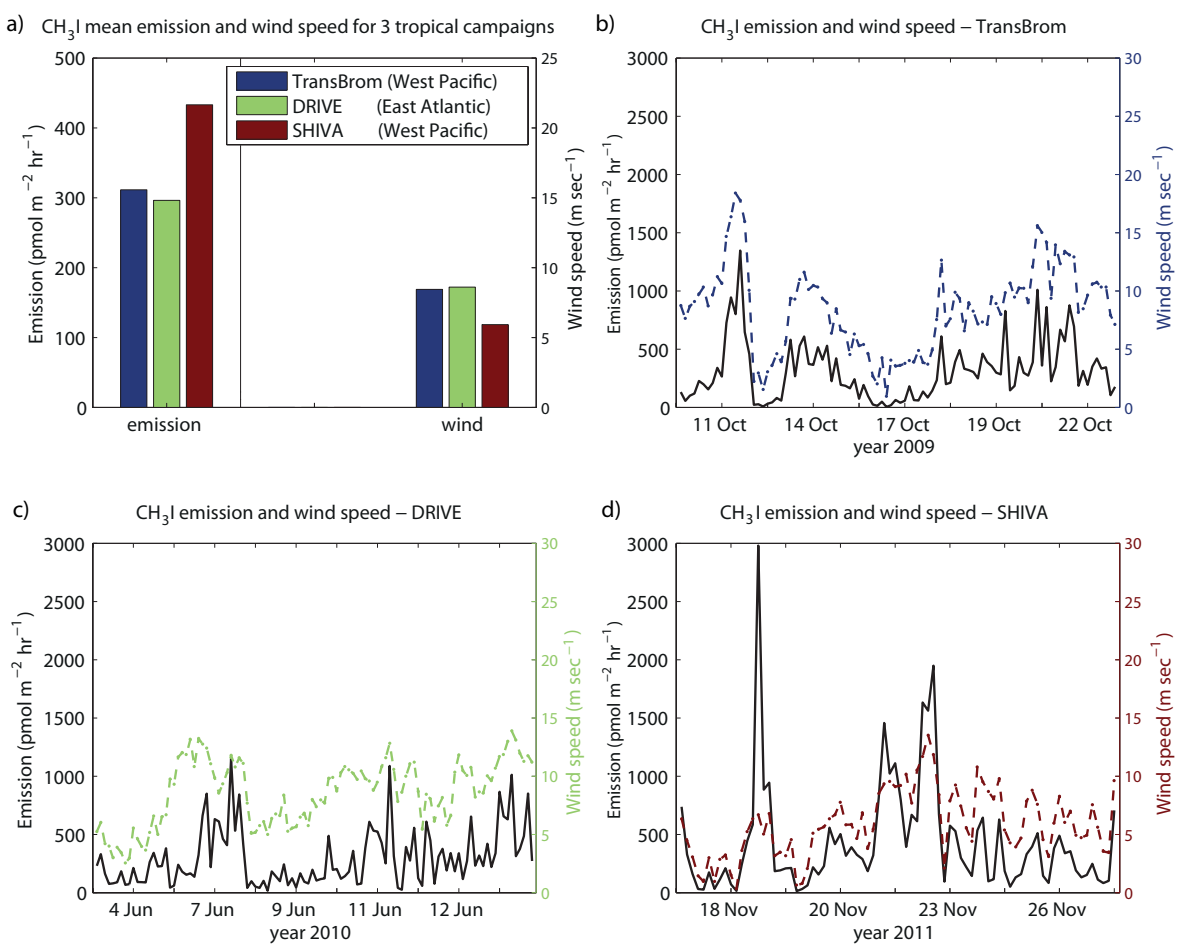

Fig. 2. Campaign-averaged $\mathrm{CH}_{3} \mathrm{I}$ emissions and wind speed are shown for three tropical campaigns (a). $\mathrm{CH}_{3} \mathrm{I}$ emissions (black line), as well as the wind speed (colored line) are displayed as a function of time along the cruise track for TransBrom (b), DRIVE (c), and SHIVA (d).

\section{Atmospheric $\mathrm{CH}_{3}$ I transport based on individual ship campaigns}

\subsection{Comparison of three tropical campaigns}

$\mathrm{CH}_{3} \mathrm{I}$ emissions observed during the tropical ship cruises vary substantially from campaign to campaign. Figure $2 \mathrm{a}$ shows the campaign-averaged emissions for all three cruises, with stronger emissions for the coastal western Pacific campaign SHIVA-Sonne (referred to as SHIVA hereinafter) compared to the northeastern Atlantic campaign DRIVE and the open western Pacific campaign TransBrom-Sonne (referred to as TransBrom hereinafter). In contrast to global estimates (Table 1), the emissions observed during the three campaigns are small with mean values of 310 (DRIVE), 320 (TransBrom) and 430 (SHIVA) pmol $\mathrm{m}^{-2} \mathrm{~h}^{-1}$ just below the minimum global estimate (443 pmol m${ }^{-2} \mathrm{~h}^{-1}$, Chuck et al., 2005) and three times smaller than the maximum global estimate (1354 pmol m ${ }^{-2} \mathrm{~h}^{-1}$, Butler et al., 2007).

Black lines in Fig. $2 b-d$ give the emission strength along the cruise tracks and demonstrate the large variability of seato-air fluxes during the campaigns, with the measurement locations often about less than $100 \mathrm{~km}$ apart. $\mathrm{CH}_{3} \mathrm{I}$ is generally oversaturated in oceanic surface waters. As a result, emission flux is primarily controlled by concentrations in water (rather than air) and the water-air exchange rate, which is in turn driven by the wind speed (Ziska et al., 2013). In ad- dition to the emission time series, the wind speed along the cruise track (colored dashed lines) for the individual campaigns is presented in Fig. 2b-d. Particularly high emissions occur for the TransBrom cruise during times of high wind speeds, e.g., emissions of up to 1364 and $600 \mathrm{pmol} \mathrm{m}^{-2} \mathrm{~h}^{-1}$ were observed during the tropical storms Nepartak and Lupit on 12 October and 14 October 2009, respectively (Quack et al., 2013).

Among the different existing parameterizations, the here applied sea-to-air flux parameterization of Nightingale et al. (2000) predicts transfer velocities in the middle range (e.g., Carpenter et al., 2012) for wind speeds below $20 \mathrm{~m} \mathrm{~s}^{-1}$. All parameterizations gain uncertainty for wind speeds above $20 \mathrm{~m} \mathrm{~s}^{-1}$ and a possible overestimation of sea-to-air fluxes at these very high wind speeds has been suggested (McNeil and D'Asaro, 2007). While this needs to be kept in mind when fluxes at higher wind speeds are considered, for the here discussed cruises wind speeds are always below $20 \mathrm{~m} \mathrm{~s}^{-1}$ and the Nightingale parameterization has been applied throughout. $\mathrm{CH}_{3} \mathrm{I}$ emissions during the DRIVE campaign are also determined by the large supersaturation in combination with varying wind speeds, with the largest emissions of up to $1146 \mathrm{pmol} \mathrm{m}^{-2} \mathrm{~h}^{-1}$ observed on 7 June 2010. For SHIVA, relatively high oceanic concentrations and warm water temperatures lead to very high supersaturations of methyl iodide in the coastal western Pacific and trigger large $\mathrm{CH}_{3} \mathrm{I}$ emissions due to elevated wind speeds. Local peak emissions 

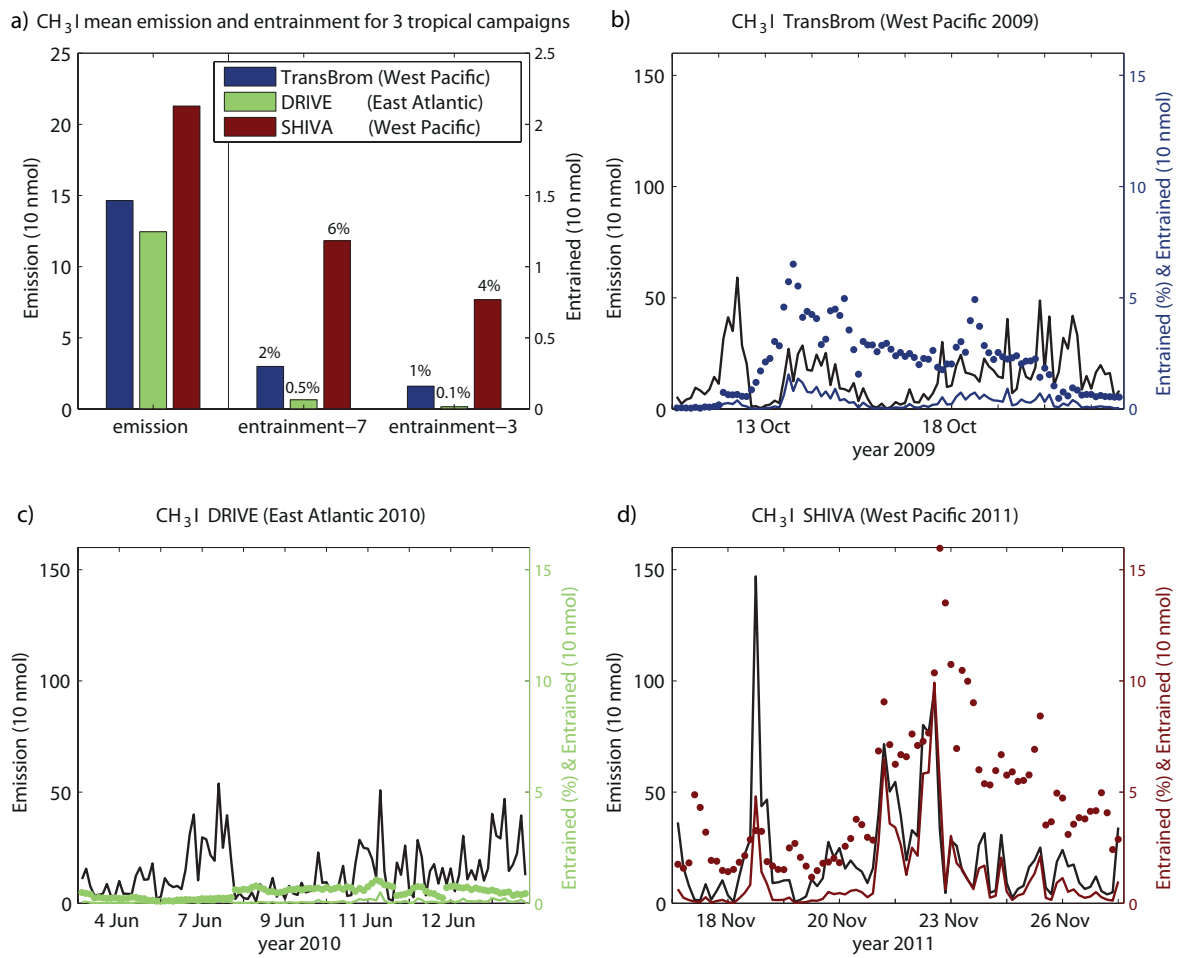

Fig. 3. Campaign-averaged $\mathrm{CH}_{3} \mathrm{I}$ emissions and modeled entrainment above $17 \mathrm{~km}$ are shown for three tropical campaigns (a). $\mathrm{CH}_{3} \mathrm{I}$ emissions (black line) as well as the relative (colored dots) and total (colored line) amount of $\mathrm{CH}_{3} \mathrm{I}$ entrained above $17 \mathrm{~km}$ are displayed as a function of time along the cruise track for TransBrom (b), DRIVE (c), and SHIVA (d). Emissions are calculated from the observed flux for a time period of one hour and an area of $500 \mathrm{~m}^{2}$ for each observation. $\mathrm{CH}_{3} \mathrm{I}$ lifetime is prescribed with 7 days (entrainment-7 in panel a and all results in b-d) or with 2-3 days (entrainment-3 in a).

during SHIVA of up to $2980 \mathrm{pmol} \mathrm{m}^{-2} \mathrm{~h}^{-1}$ (19 November 2011) exceed the maximum emissions observed during the other two campaigns and are among the largest local emissions observed so far (Ziska et al., 2013).

The amount of $\mathrm{CH}_{3} \mathrm{I}$ that reaches the stratosphere has been estimated based on Lagrangian transport calculations with FLEXPART. $\mathrm{CH}_{3} \mathrm{I}$ emissions in the FLEXPART runs are calculated from the observed flux for a time period of one hour and an area of $500 \mathrm{~m}^{2}$ for each observation, presented in Fig. 3 as campaign averages (Fig. 3a) and as time series over the length of each individual campaign (Fig. 3b-d). The level above which no significant washout is expected is particularly important for stratospheric iodine chemistry, since all $\mathrm{CH}_{3} \mathrm{I}$ which reaches this level before being photolyzed can be expected to contribute to the stratospheric $\mathrm{I}_{\mathrm{y}}$ budget. While the exact altitude of the "no-washout level" is still under debate (Fueglistaler et al., 2009), we have chosen the cold point altitude as an upper estimate since no dehydration is expected to occur above. Based on evaluations of regular radiosonde measurements during the ship campaigns, the cold point is found at $17 \mathrm{~km}$ (Fuhlbrügge et al., 2013; Krüger and Quack, 2012). We quantify the contribution of $\mathrm{CH}_{3} \mathrm{I}$ to stratospheric iodine based on the amount of $\mathrm{CH}_{3} \mathrm{I}$ entrained above $17 \mathrm{~km}$, which is calculated as the sum of $\mathrm{CH}_{3} \mathrm{I}$ carried by all the computational particles across this altitude. Note that the altitude of the level above which no washout occurs is a source of uncertainty regarding our results of the $\mathrm{CH}_{3} \mathrm{I}$ contribution to stratospheric iodine. If, for instance, heterogeneous recycling of iodine from aerosols back to the gas phase were to occur (Dix et al., 2013), the "no-washout level" would be lower than the cold point and, as a consequence, the $\mathrm{CH}_{3} \mathrm{I}$ contribution to stratospheric iodine would be larger than estimated below. A simple sensitivity study reveals that approximately twice as much $\mathrm{CH}_{3} \mathrm{I}$ is found to contribute to the stratospheric iodine if the "no-washout level" is set at $16 \mathrm{~km}$ instead of $17 \mathrm{~km}$.

For all three campaigns the average amount of $\mathrm{CH}_{3} \mathrm{I}$ being entrained above $17 \mathrm{~km}$ is shown in Fig. 3a. For the scenario of a uniform atmospheric lifetime of 7 days (WMO, 2011), about $0.5 \%$ (DRIVE), $2 \%$ (TransBrom) and $6 \%$ (SHIVA) of the emitted $\mathrm{CH}_{3} \mathrm{I}$ reaches the upper TTL and is projected to be entrained into the stratosphere. In order to investigate the sensitivity of our results to the prescribed atmospheric lifetime of $\mathrm{CH}_{3} \mathrm{I}$, we repeat the same calculation but using an altitude dependent $\mathrm{CH}_{3} \mathrm{I}$ lifetime from the TOMCAT CTM. When the considerably shorter profile lifetime (2-3 days) is assumed, only $0.1 \%$ (DRIVE), $1 \%$ (TransBrom) and $4 \%$ (SHIVA) of the emitted $\mathrm{CH}_{3} \mathrm{I}$ are transported into the upper 
TTL. The entrainment of $\mathrm{CH}_{3} \mathrm{I}$ above $17 \mathrm{~km}$ based on the two different lifetimes reveals considerable differences, as one would expect, and illustrates the need for a better understanding of tropospheric $\mathrm{CH}_{3} \mathrm{I}$ chemistry. While all the following results are based on assuming a $\mathrm{CH}_{3} \mathrm{I}$ atmospheric lifetime of 7 days, the case study above provides an estimate of the sensitivity of our results (30-80\% less entrainment) to variations of the atmospheric lifetime (2.5-3 days instead of 7 days).

The efficiency of atmospheric $\mathrm{CH}_{3} \mathrm{I}$ transport from the surface to the cold point (given by the percentage value of $\mathrm{CH}_{3} \mathrm{I}$ reaching $17 \mathrm{~km}$ ) during SHIVA (western Pacific) is 12 to 40 times larger than the efficiency of $\mathrm{CH}_{3} \mathrm{I}$ transport during DRIVE (Atlantic). While these results are derived from model runs based on local campaign data, it is known from previous studies that the western Pacific is in general an important region for troposphere-stratosphere transport of short-lived compounds (e.g., Aschmann et al., 2009; Krüger et al., 2009; Levine et al., 2007) due to active deep convection (Fueglistaler et al., 2009 and references therein). For SHIVA, the large emissions together with the very efficient vertical transport lead to an overall large amount of $\mathrm{CH}_{3} \mathrm{I}$ reaching the stratosphere. The absolute amounts of $\mathrm{CH}_{3} \mathrm{I}$ being entrained above the cold point at $17 \mathrm{~km}$ are given in Fig. 3a for all campaigns, illustrating that 20 times more $\mathrm{CH}_{3} \mathrm{I}$ is entrained for SHIVA compared to DRIVE and 4 times more when compared to TransBrom.

\subsection{Possible connection between $\mathrm{CH}_{3} \mathrm{I}$ emissions and atmospheric transport}

Oceanic emissions and atmospheric transport vary from campaign to campaign but also considerably within each campaign. Dotted lines in Fig. 3b, c, and d give the transport efficiency along the cruise track and demonstrate its large variability from measurement side to measurement side. During DRIVE, the $\mathrm{CH}_{3} \mathrm{I}$ troposphere-stratosphere transport is weak for the whole campaign and less than $1 \%$ reaches the stratosphere (Fig. 3c). However, for the two western Pacific campaigns, the vertical transport is more efficient, lifting $1-16 \%$ of emitted $\mathrm{CH}_{3} \mathrm{I}$ from the surface to $17 \mathrm{~km}$ for SHIVA, and $0-6 \%$ for TransBrom. While both ship campaigns took place in the western Pacific and encountered periods of strong convective activity, the amount of overshooting convection responsible for the transport of the short-lived $\mathrm{CH}_{3} \mathrm{I}$ up to $17 \mathrm{~km}$ differs between the campaigns. An overall stronger vertical transport is predicted for the SHIVA campaign, which took place in the coastal regions of the maritime continent, an area well known for deep cumulus convection and heavy precipitation systems during boreal winter (Chang et al., 2005). For TransBrom, convection above the open ocean including tropical storm systems dominates the vertical transport from the surface to the cold point at $17 \mathrm{~km}$. The total amount of $\mathrm{CH}_{3} \mathrm{I}$ entrained above $17 \mathrm{~km}$ shows maximum values for cases when both variables, emission and transport efficiency, are large. For the SHIVA campaign, this coincidence is found for the event of the second largest emission on 22 November 2011, where the transport model estimates that around $10 \% \mathrm{CH}_{3} \mathrm{I}$ could reach $17 \mathrm{~km}$. For TransBrom, the largest total entrainment takes place on 14 October 2009 and is based on an average emission value during times of maximum efficiency of vertical transport.

In order to further analyze possible coincidences of strong emissions and efficient vertical transport, a correlation analysis has been applied to the two time series. For the entire time series covering the whole cruise length, no correlation exists for any of the three campaigns. However, when parts of the time series are analyzed, high correlations are found. For the TransBrom campaign, correlations between emissions and vertical atmospheric transport reach a maximum for two individual campaign sections (Fig. 4a). A very high correlation of 0.89 is found for the first section, comprising 16 data points collected over 2 days (red lines). A high correlation $(r=0.69)$ also exists for the subsequent cruise section extending from 13 October 2009 to 18 October 2009 based on 39 data points. All correlation coefficients are statistically significant at the $95 \%$ confidence level based on the Student's $t$ test. Scatter plots of the emissions versus vertical atmospheric transport show different relationships for the two periods, with linear fits resulting in slopes of 54 and 5 , respectively.

Understanding the two different regimes occurring during TransBrom, which show correlations if analyzed separately, but lead to uncorrelated data sets when combined, requires some background information on the meteorological situation during the cruise (Krüger and Quack, 2012). The first cruise section extends north of the Intertropical Convergence Zone (ITCZ) from $32^{\circ} \mathrm{N}$ to $24^{\circ} \mathrm{N}$, and model results suggest that vertical transport from the surface to $17 \mathrm{~km}$ is weak with less than $1 \%$ of $\mathrm{CH}_{3} \mathrm{I}$ being lifted by deep convection into the upper TTL. At the end of the first cruise section $\left(12\right.$ October $\left.2009,27^{\circ} \mathrm{N}\right)$, the ship crossed the track of the tropical storm Nepartak and large horizontal wind speeds reaching values of $20.4 \mathrm{~m} \mathrm{~s}^{-1}$ were observed. Measurements were increased to an hourly frequency and peak emissions of oceanic $\mathrm{CH}_{3} \mathrm{I}$ were reported during periods of maximum horizontal winds. Note that during the influence of Nepartak, the transport model shows strong convective activity, reaching only main convective outflow regions around $12 \mathrm{~km}$ and not the upper TTL, resulting in the weak transport efficiency discussed above. At the beginning of the second cruise section, the ship crossed the ITCZ and came close to the tropical storm Lupit (14 October $2009,18^{\circ} \mathrm{N}$ ), which developed into a super typhoon a couple of days later (Krüger and Quack, 2012). Similar to the situation during Nepartak, the strong horizontal wind speeds are accompanied by increased atmospheric trace gas concentrations and emissions. As opposed to the first cruise track section, atmospheric transport into the upper TTL is very efficient during the second cruise section, in accordance with its location within the ITCZ. 

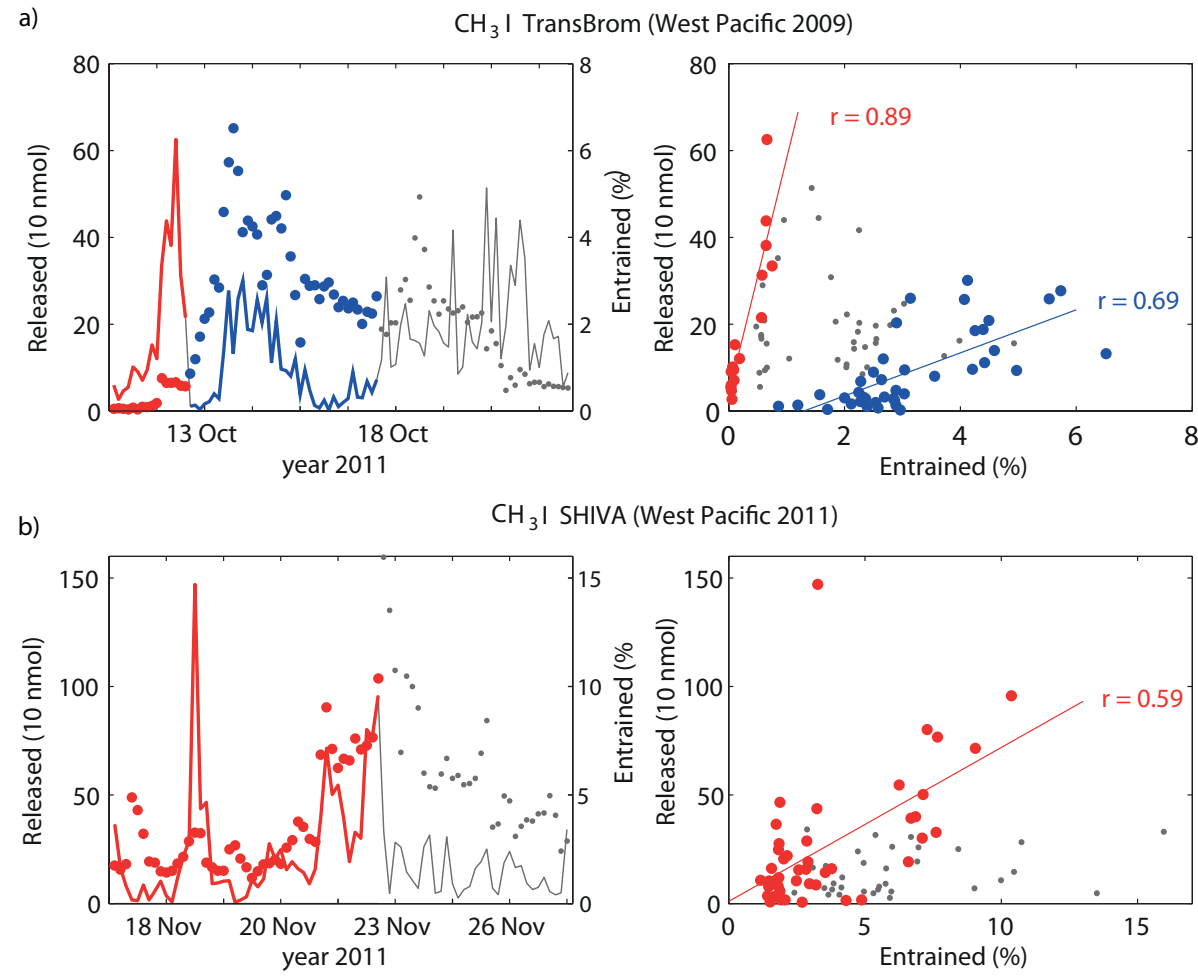

Fig. 4. The $\mathrm{CH}_{3} \mathrm{I}$ observed emissions (line) and the modeled relative amount entrained above $17 \mathrm{~km}$ (dots) are shown for TransBrom (a) and SHIVA (b) as a function of time (left panels) and as a scatter plot (right panels). The subsets, for which correlations between the two functions have been identified, are color-coded in red and blue. The correlation coefficients $(r)$ are given in the right panel.

Table 4. Correlation coefficients between $\mathrm{CH}_{3} \mathrm{I}$ emission, horizontal wind speed and vertical transport efficiency (given by the relative amount of $\mathrm{CH}_{3} \mathrm{I}$ entrained above $17 \mathrm{~km}$ ). The coefficients are given for the entire TransBrom and SHIVA campaigns as well as for the subsets where correlations between the $\mathrm{CH}_{3} \mathrm{I}$ emissions and vertical transport efficiency have been identified (TransBrom section 1 and 2 , SHIVA section 1).

\begin{tabular}{lrrrrr}
\hline $\begin{array}{l}\text { Correlation coefficients } \\
\text { for various cruise sections }\end{array}$ & $\begin{array}{r}\text { TransBrom } \\
\text { section 1 }\end{array}$ & $\begin{array}{r}\text { TransBrom } \\
\text { section 2 }\end{array}$ & $\begin{array}{r}\text { TransBrom } \\
\text { entire }\end{array}$ & $\begin{array}{r}\text { SHIVA } \\
\text { section 1 }\end{array}$ & $\begin{array}{r}\text { SHIVA } \\
\text { entire }\end{array}$ \\
\hline $\begin{array}{l}\mathrm{CH}_{3} \text { I emission } \\
\text { and horizontal wind speed }\end{array}$ & 0.93 & 0.93 & 0.82 & 0.70 & 0.62 \\
\hline $\begin{array}{l}\text { Horizontal wind speed } \\
\text { and vertical transport }\end{array}$ & 0.87 & 0.74 & -0.29 & 0.73 & 0.49 \\
\hline $\begin{array}{l}\mathrm{CH}_{3} \text { I emission } \\
\text { and vertical transport }\end{array}$ & 0.89 & 0.69 & -0.05 & 0.59 & 0.28 \\
\hline
\end{tabular}

For the SHIVA campaign, the correlation between oceanic emissions and atmospheric transport reaches a maximum for the cruise section in the South China Sea from 17 November to 23 November 2011, comprising 47 data points. Figure $4 \mathrm{~b}$ shows the two time series, oceanic emissions and troposphere-stratosphere transport efficiency, with the data during the respective cruise section displayed in red. The correlation $(r=0.59)$ results mostly from the fact that the large emissions on 21-22 November 2011 are accompanied by fast vertical transport. Note that for these two days high horizontal wind speeds of up to $13 \mathrm{~m} \mathrm{~s}^{-1}$ occurred, while the horizontal winds during the time period before were moderate, around $5 \mathrm{~m} \mathrm{~s}^{-1}$. After 23 November 2011, the horizontal winds and also the vertical transport continued to be large; however, due to lower oceanic concentrations and saturation anomalies the emissions are small compared with the first cruise section.

Based on two tropical campaigns in the western Pacific, three cruise sections have been identified that show a correlation between the amount of $\mathrm{CH}_{3} \mathrm{I}$ emitted from the ocean 
and the fraction of emitted $\mathrm{CH}_{3} \mathrm{I}$ transported from the surface to the cold point at $17 \mathrm{~km}$. In general, $\mathrm{CH}_{3} \mathrm{I}$ shows relatively uniform oceanic concentrations over the various cruise sections (Quack et al., 2013). Emission rates are mainly determined by the wind speed variations with high wind speeds resulting in a fast atmospheric outflow and an immediate replacement of the gas from the oceanic source. Such correlations between emissions and horizontal wind speeds have also been observed for other short-lived halogenated gases such as $\mathrm{CHBr}_{3}$ and $\mathrm{CH}_{2} \mathrm{Br}_{2}$ in supersaturated coastal waters during tropical storm activities (Zhou et al., 2008). We find the strongest $\mathrm{CH}_{3} \mathrm{I}$ emissions during tropical storms, which on the other hand can lead to intense vertical transport associated with developing tropical cyclones. It has been suggested that tropical cyclones could play an important role for troposphere-stratosphere exchange due to associated frequent convective overshooting (Rossow and Pearl, 2007) and due to contributing a disproportional large amount of the convection that penetrates the stratosphere (Romps and Kuang, 2009). The mechanism of strong horizontal winds triggering large emissions, on the one hand, and being associated with tropical convective systems, on the other hand, could provide a possible explanation of the identified correlations. Such a mechanism could also explain why data over longer time periods are uncorrelated if the meteorological or oceanic regime changes. Examples are the change in oceanic $\mathrm{CH}_{3} \mathrm{I}$ concentration gradients during SHIVA on 23 November 2011 coinciding with the end of the correlation time period and the change of meteorological conditions during TransBrom on 14 October, across the ITCZ, coinciding with the switch between the two correlation regimes.

Correlation coefficients between all three quantities are presented in Table 4 for different sections of the two cruises. Evidently, in all cases there is a strong correlation between $\mathrm{CH}_{3} \mathrm{I}$ emissions and the horizontal wind speed. When the horizontal surface wind is also strongly correlated with the efficiency of vertical transport, we find the above discussed correlation between $\mathrm{CH}_{3} \mathrm{I}$ emissions and vertical transport. The fact that for these cases both quantities are highly correlated with the horizontal wind further strengthens the above suggested mechanism. For the entire TransBrom cruise, no correlation of the horizontal winds with the vertical transport can be found, probably due to the very different meteorological regimes. For the entire SHIVA campaign, the correlation between $\mathrm{CH}_{3} \mathrm{I}$ emission and horizontal winds is somewhat weaker than for the other cases, probably because of a switch in the oceanic regime.

For the cruise sections where a correlation between emission and vertical transport could be identified, one also finds the overall largest amounts of $\mathrm{CH}_{3} \mathrm{I}$ being transported into the stratosphere. For TransBrom, the maximum amount of $0.1 \mathrm{ppt} \mathrm{CH} \mathrm{CH}_{3} \mathrm{I}$ at $17 \mathrm{~km}$ (Fig. 5) is associated with emissions on 14 October 2009 and subsequent atmospheric transport influenced by the tropical storm Lupit. Atmospheric $\mathrm{CH}_{3} \mathrm{I}$ abundance at $17 \mathrm{~km}$ averaged over the whole campaign amounts

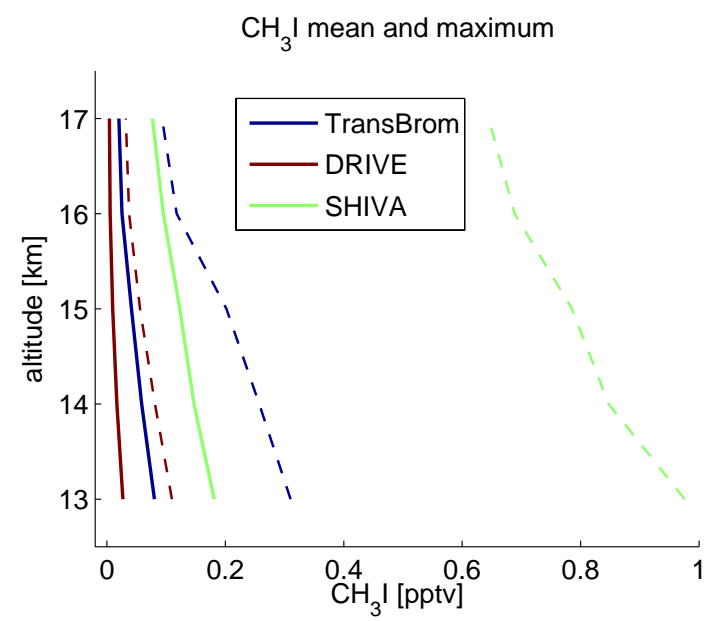

Fig. 5. Modeled $\mathrm{CH}_{3} \mathrm{I}$ profiles based on observed emissions during the TransBrom, DRIVE and SHIVA ship campaigns. For all three campaigns mean values (solid lines) and maximum values (dashed lines) are given.

to 0.02 ppt. During SHIVA, very large peak emissions as well as very intense vertical transport result in model estimates of $0.6 \mathrm{ppt} \mathrm{CH}_{3} \mathrm{I}$ at $17 \mathrm{~km}$ (Fig. 5), which is much larger than any values reported by high reaching aircraft measurements so far (Montzka and Reimann, 2011). The campaign average mixing ratio at $17 \mathrm{~km}$ is considerably lower, amounting to $0.07 \mathrm{ppt}$. During DRIVE, the maximum values at $17 \mathrm{~km}$ range around $0.03 \mathrm{ppt}$ and mean values are in the order of $0.01 \mathrm{ppt}$ (Fig. 5). Note that in the free troposphere, the $\mathrm{CH}_{3} \mathrm{I}$ estimates are of similar order of magnitude as recent observations of inorganic iodine (Puentedura et al., 2012; Dix et al., 2013). In order to investigate whether the relatively large mixing ratios in the upper TTL estimated for the western Pacific emissions are isolated cases, strongly deviating from otherwise low $\mathrm{CH}_{3} \mathrm{I}$ abundances, or if they occur frequently enough to impact global $\mathrm{CH}_{3} \mathrm{I}$, we analyze global model runs in the next section.

\section{Global atmospheric $\mathrm{CH}_{3} \mathrm{I}$ transport}

\subsection{Comparison with aircraft measurements in the lower TTL}

The global contribution of $\mathrm{CH}_{3} \mathrm{I}$ to the stratospheric iodine budget is estimated from FLEXPART model runs using a global emission climatology provided by Ziska et al. (2013) as input data. The emission maps have been derived from individual campaign measurements; however, as a result of the averaging process they do not represent the full spread of the original data. Furthermore, they do not include instantaneous peak emissions that might be correlated to the subsequent atmospheric transport, as illustrated above for individual campaigns. Figure 6 presents the $40^{\circ} \mathrm{S}-40^{\circ} \mathrm{N}$ section of 

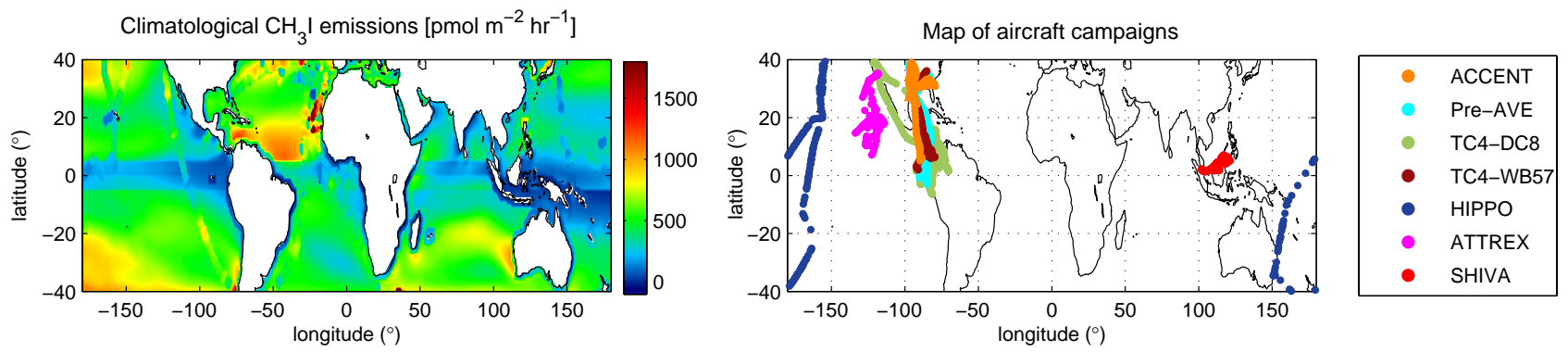

Fig. 6. Climatological $\mathrm{CH}_{3} \mathrm{I}$ emissions [pmol m${ }^{-2} \mathrm{~h}^{-1}$ ] visualized between $40^{\circ} \mathrm{S}$ and $40^{\circ} \mathrm{N}$ on a $1^{\circ} \times 1^{\circ}$ grid from Ziska et al. (2013) (a). Locations of aircraft campaign measurements for the ACCENT, Pre-AVE, TC4, HIPPO2, ATTREX, and SHIVA missions (b).

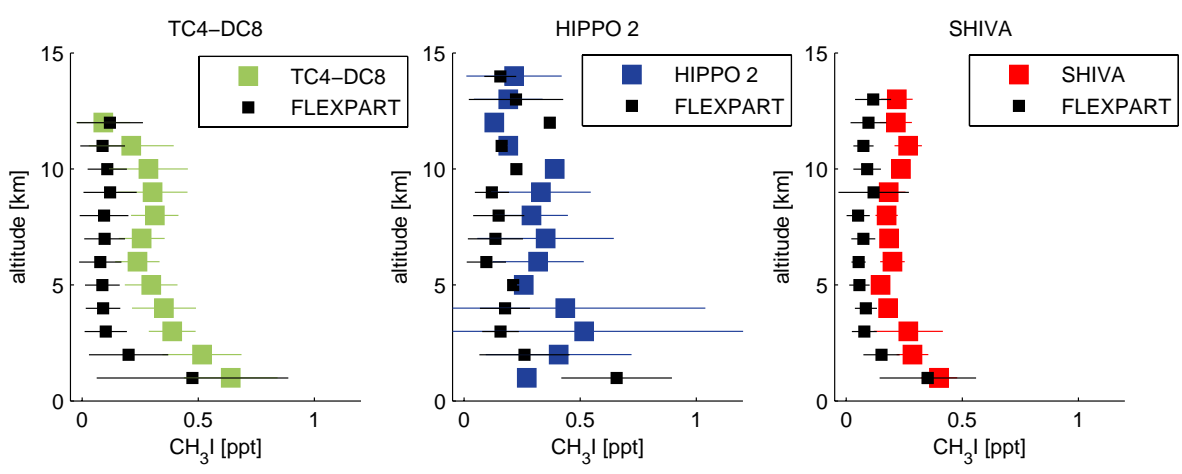

Fig. 7. Comparison between observed and modeled vertical profiles of $\mathrm{CH}_{3} \mathrm{I}$ in the troposphere and lower TTL. Observations from all tropical flight sections of each aircraft campaign are used to find coincident model output. Observations and model results are averaged over all coincident data points in $1 \mathrm{~km}$ wide vertical intervals for TC4-DC8 (left panel), HIPPO2 (middle panel), and SHIVA (right panel). Horizontal bars indicate \pm 1 standard deviation.

the emission climatology. Due to supersaturated oceans the climatological emissions are nearly everywhere positive and only a very few grid points denote $\mathrm{CH}_{3} \mathrm{I}$ sinks. Large oceanic sources are found in the subtropical gyre regions as well as in North Atlantic. The tropical western Pacific region shows particularly low $\mathrm{CH}_{3} \mathrm{I}$ emissions. Recent observations in this region during the SHIVA ship campaign, which have not been included in the climatology compilation so far, suggest the climatology might underestimate western Pacific emissions.

We compare modeled $\mathrm{CH}_{3} \mathrm{I}$ abundances to available aircraft measurements in the free troposphere and TTL region. A special focus is on the model-measurement comparison in the upper TTL and on the question whether the aircraft measurements available here are representative of existing global estimates. The comparison is based on model runs carried out for the time period of the respective campaign and uses global emission climatologies as input data. As a result we expect the modeled atmospheric transport to represent the atmospheric conditions during the campaign, even though the climatological emissions might deviate from the true local emissions present at the time. A geographic map of the flight tracks is shown in Fig. 6. In a first step, coincident data points for observations and model output are identified if they are less than $12 \mathrm{~h}$ apart and if their distance is less than $0.5^{\circ}$ horizontally and less than $0.5 \mathrm{~km}$ vertically. Profile comparisons are determined for each campaign by taking the mean and standard deviation over all coincidences identified for the particular campaign data and for the corresponding model output.

The profile comparison for the three aircraft campaigns, which provide data in the free troposphere and lower UTLS, show in general a good agreement between the observations and the model results, with the latter being consistently lower (Fig. 7). For TC4-DC8, the modeled profile shows a steeper vertical gradient between 1 and $3 \mathrm{~km}$ than the observations, leading to some disagreement below $5 \mathrm{~km}$. Above this level, model output and observations agree within their respective standard deviations. The HIPPO2 flight tracks extend over all tropical latitudes and campaign averaged profiles show a large variability below $10 \mathrm{~km}$ and around $13-14 \mathrm{~km}$, which is also displayed although somewhat weaker by the model results. Mean values agree very well on some levels (e.g., above $10 \mathrm{~km}$ ) but show larger discrepancies on other levels (e.g., 3-4 km). For SHIVA, the variability over all flight sections is small for observations and model results. In general, observed and modeled profiles show a very similar shape with FLEXPART results being slightly smaller consistently 

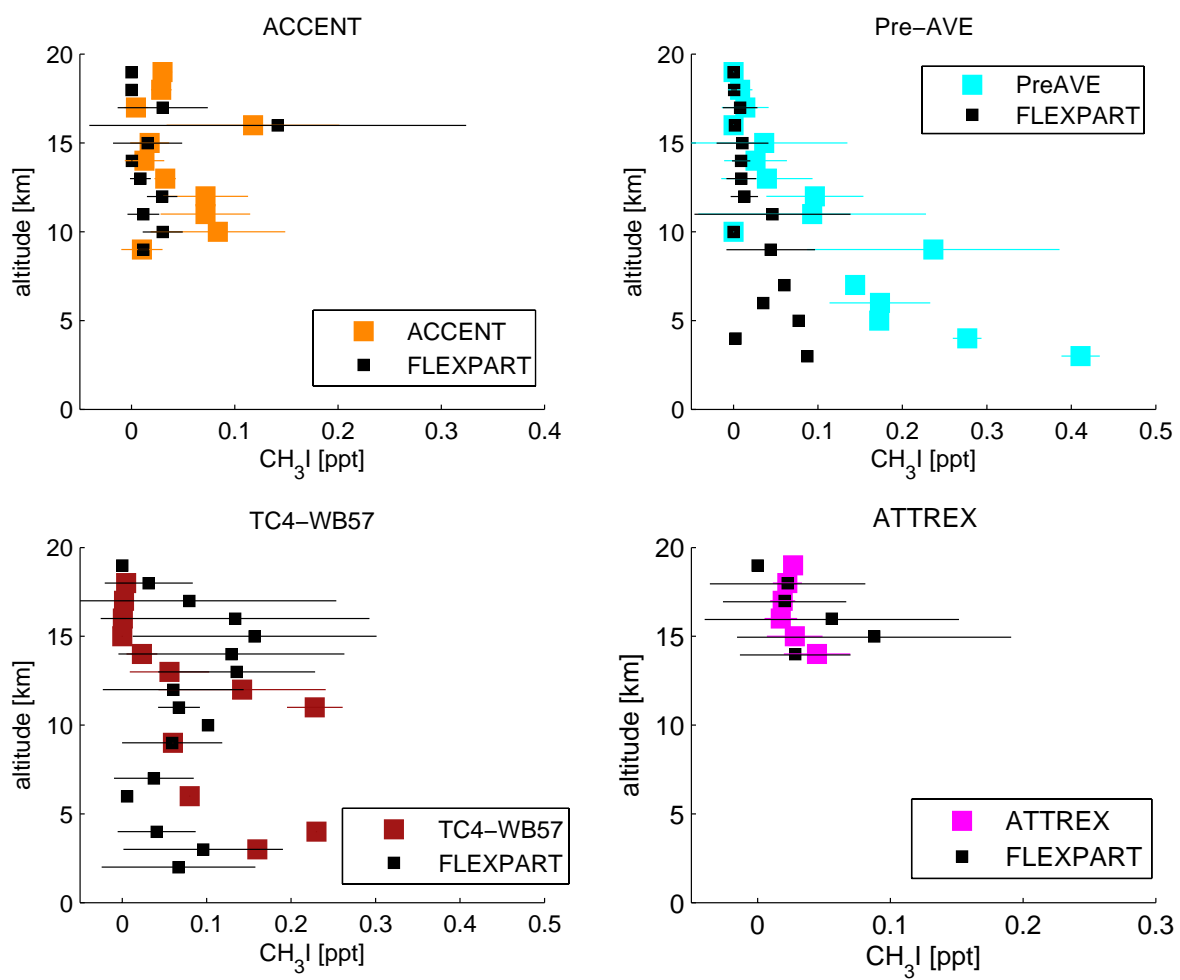

Fig. 8. Same as Fig. 7 for vertical profiles of $\mathrm{CH}_{3} \mathrm{I}$ in the troposphere and TTL for the aircraft campaigns ACCENT, Pre-AVE, TC4-WB57, and ATTREX.

over the whole altitude range. The largest differences are found around $11 \mathrm{~km}$. For some individual flights, convective outflow leads to observations of enhanced $\mathrm{CH}_{3} \mathrm{I}$ between 10 and $12 \mathrm{~km}$ that result in a "C-shape" profile, a characteristic which is well captured by the model results (not shown here).

\subsection{Comparison with aircraft measurements in the upper TTL}

Model-measurement comparisons for the four campaigns conducted with the high-altitude aircraft sampling in the upper TTL and lower stratosphere are shown in Fig. 8. For three out of four campaigns, the modeled abundances above $10 \mathrm{~km}$ agree very well with the observations. For all three cases, the mixing ratios in the upper TTL are below $0.1 \mathrm{ppt}$, with the exception of the strongly enhanced mixing ratios at $16 \mathrm{~km}$ during ACCENT, which are reported by the observations and the model results. Largest discrepancies are found for the TC4-WB57 campaign, where basically no $\mathrm{CH}_{3} \mathrm{I}$ was observed above $15 \mathrm{~km}$ while FLEXPART simulates mixing ratios around $0.1 \mathrm{ppt}$ for the levels $13-17 \mathrm{~km}$. Only below 10 and above $17 \mathrm{~km}$ does the model output agree well with the TC4-WB57 observations. A summary of the modelmeasurement comparison in the TTL is displayed in Fig. 9, where the modeled and observed profiles averaged over all four campaigns are displayed. FLEXPART overestimates the amount of $\mathrm{CH}_{3} \mathrm{I}$ observed at $17-18 \mathrm{~km}(0.01 \mathrm{ppt})$ simulating a too strong $\mathrm{CH}_{3} \mathrm{I}$ entrainment. However, the model results underestimate $\mathrm{CH}_{3} \mathrm{I}$ at $19 \mathrm{~km}$, which observations suggest to be around 0.02 ppt. Since $\mathrm{CH}_{3} \mathrm{I}$ has no source in the atmosphere, one would expect to find lower values at higher altitudes. A horizontally moving aircraft, however, will probe different air masses at the different altitude levels, and a positive vertical gradient, as noted between 17 and $19 \mathrm{~km}$, can occur. The overall comparison of the $17-19 \mathrm{~km}$ region gives a good agreement between observations $(0.011-0.019 \mathrm{ppt})$ and model results $(0.006-0.032 \mathrm{ppt})$.

\subsection{Global $\mathrm{CH}_{3} \mathrm{I}$ in the upper TTL}

It is also of interest to estimate $\mathrm{CH}_{3} \mathrm{I}$ abundances in regions where no in situ measurements in the upper TTL are available. The projected amount of $\mathrm{CH}_{3} \mathrm{I}$ entrained into the stratosphere depends on various FLEXPART model parameters and their associated uncertainties such as in the convective parameterization and in the vertical transport driven by the vertical wind fields. The accurate representation of convection has been validated with tracer experiments and

${ }^{222} \mathrm{Rn}$ measurements (Forster et al., 2007). The application of transport timescales based on vertical heating rates instead of vertical wind fields in the TTL between 15 and $17 \mathrm{~km}$ results in only minor differences of VSLS entrainment (Tegtmeier et al., 2012). As discussed earlier, our results are also constrained by the prescribed $\mathrm{CH}_{3} \mathrm{I}$ lifetime, which can 


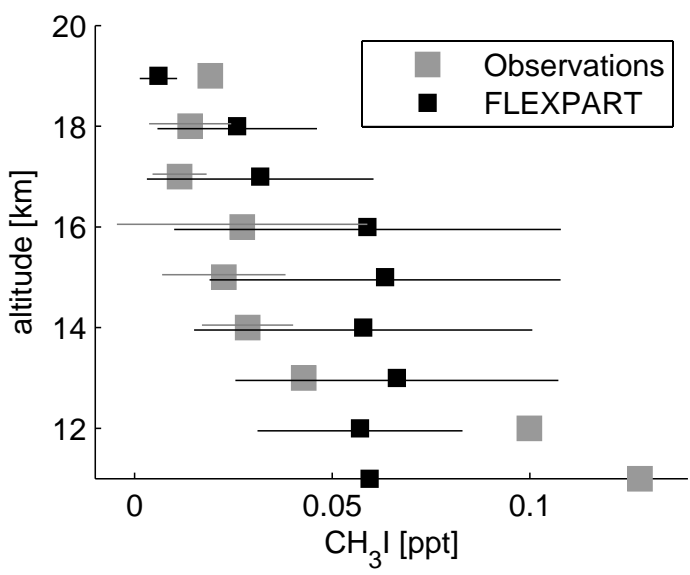

Fig. 9. Comparison between observed and modeled vertical profiles of $\mathrm{CH}_{3} \mathrm{I}$ in the upper troposphere and TTL. Observations and model results are averaged over all data campaign-averaged profiles that include measurements in the upper TTL (ACCENT, Pre-AVE, TC4-WB57, and ATTREX). Horizontal bars indicate \pm 1 standard deviation.

cause variations of $\mathrm{CH}_{3} \mathrm{I}$ entrainment into the stratosphere of around $50 \%$. However, the overall good agreement between model and observations in the eastern Pacific encourages the use of the FLEXPART model results for further analysis.

The western Pacific region is of particular interest for the troposphere-stratosphere transport, and we will evaluate how the FLEXPART results in this area compare to the model results and observations in the eastern Pacific. Such a comparison will allow speculations of how representative global estimates are of existing aircraft measurements. In Fig. 10a observations averaged over four tropical campaigns that crossed the eastern Pacific are displayed together with FLEXPART results averaged over three regions: the whole tropical belt $\left(30^{\circ} \mathrm{N}-30^{\circ} \mathrm{S}\right)$, the tropical western Pacific, and the tropical eastern Pacific aircraft campaign area. While for the western Pacific and the tropical belt the 2009 annual mean is displayed, the eastern Pacific average is based on the months when aircraft measurements are available (see Table 3) in order to allow for a comparison of the modeled eastern Pacific mean values with the in situ observations. The observations and model results for the eastern Pacific agree quite well, as discussed above for the comparisons based on coincidences. While observations suggest 0.01 ppt $\mathrm{CH}_{3} \mathrm{I}$ at $17 \mathrm{~km}$, the modeled profile shows slightly larger values of $0.02 \mathrm{ppt}$. Overall, the comparison indicates that the available in situ measurements provide representative estimates of the mean $\mathrm{CH}_{3} \mathrm{I}$ abundance in the eastern Pacific region. FLEXPART results for the western Pacific region show considerably larger mixing ratios, especially between 14 and $18 \mathrm{~km}$ with $0.08 \mathrm{ppt}$ $\mathrm{CH}_{3} \mathrm{I}$ at $17 \mathrm{~km}$. The geographical distribution of the mixing ratios is displayed in Fig. 10b, indicating that the western Pacific region between $100^{\circ} \mathrm{W}$ and $150^{\circ} \mathrm{E}$ shows the largest $\mathrm{CH}_{3} \mathrm{I}$ abundances. Our model does not take into account ter- restrial $\mathrm{CH}_{3} \mathrm{I}$ emissions and therefore the very-short lived $\mathrm{CH}_{3} \mathrm{I}$ is projected to reach the cold point and enter the stratosphere mostly above the oceans.

The average entrainment of $\mathrm{CH}_{3} \mathrm{I}$ into the stratosphere amounts to $0.04 \mathrm{ppt}$, as demonstrated by the tropical mean $\left(30^{\circ} \mathrm{S}-30^{\circ} \mathrm{N}\right) \mathrm{CH}_{3} \mathrm{I}$ profile (Fig. 10a). In the annual mean distribution the entrainment is focused on the inner tropical latitude bands, mainly between $20^{\circ} \mathrm{S}$ and $20^{\circ} \mathrm{N}$ where the mean mixing ratio is about 0.05 ppt. Figure 11 provides information on the frequency occurrence of $\mathrm{CH}_{3} \mathrm{I}$ mixing ratios at $17 \mathrm{~km}$ between $20^{\circ} \mathrm{S}$ and $20^{\circ} \mathrm{N}$. As already evident from the geographical distribution of $\mathrm{CH}_{3} \mathrm{I}$ abundances (Fig. 10), most values range between 0 and $0.1 \mathrm{ppt}(82 \%)$. However, a small amount of air is projected to carry larger amounts of $\mathrm{CH}_{3} \mathrm{I}$, with $5.5 \%$ of air having mixing ratios larger than $0.2 \mathrm{ppt}$. Mixing ratios above $0.4 \mathrm{ppt}$ occur only very rarely $(0.6 \%)$, while mixing ratios above $0.6 \mathrm{ppt}$ occur only in less than $0.1 \%$ of all air masses. The results from the global $\mathrm{CH}_{3} \mathrm{I}$ model run show that the estimates from ship campaigns for TransBrom and SHIVA (0.02 and $0.07 \mathrm{ppt}$, respectively) are in the general range of values found in the western Pacific. Some in situ peak emissions observed during SHIVA combined with subsequent strong vertical transport lead to extremely high $\mathrm{CH}_{3} \mathrm{I}$ abundances at $17 \mathrm{~km}(\sim 0.6 \mathrm{ppt})$, which are expected to occur in less than $0.1 \%$ of all events based on global model projections.

\section{Summary and discussion}

Our study follows a two-way approach for modeling upper air $\mathrm{CH}_{3} \mathrm{I}$ abundances. One method uses highly localized $\mathrm{CH}_{3} \mathrm{I}$ emissions estimated during three ship campaigns to study the detailed characteristics of $\mathrm{CH}_{3} \mathrm{I}$ transport from the ocean surface through the TTL up to the cold point. The second approach uses global climatological emissions to estimate the global strength and geographical distribution of $\mathrm{CH}_{3} \mathrm{I}$ entrainment into the tropical stratosphere. Model results are compared to measurements from high-altitude aircraft campaigns currently available in the eastern Pacific region.

The detailed analysis of $\mathrm{CH}_{3} \mathrm{I}$ emissions and transport for three individual ship campaigns reveals that the emissions vary by about $50 \%$ from campaign to campaign, but show much larger variations within one campaign. The large variability between measurements is supposedly related to the varying meteorological conditions, in particular to the variations of the horizontal winds. It is of interest to estimate to what degree one needs to know this variability in order to realistically simulate the $\mathrm{CH}_{3} \mathrm{I}$ transport from the surface into the stratosphere. Especially if the $\mathrm{CH}_{3} \mathrm{I}$ emissions and the intensity of vertical transport are correlated, coarse model simulations could potentially over- or underestimate atmospheric $\mathrm{CH}_{3} \mathrm{I}$ abundances. While such correlations have not been observed over the entire length of one ship campaign, 

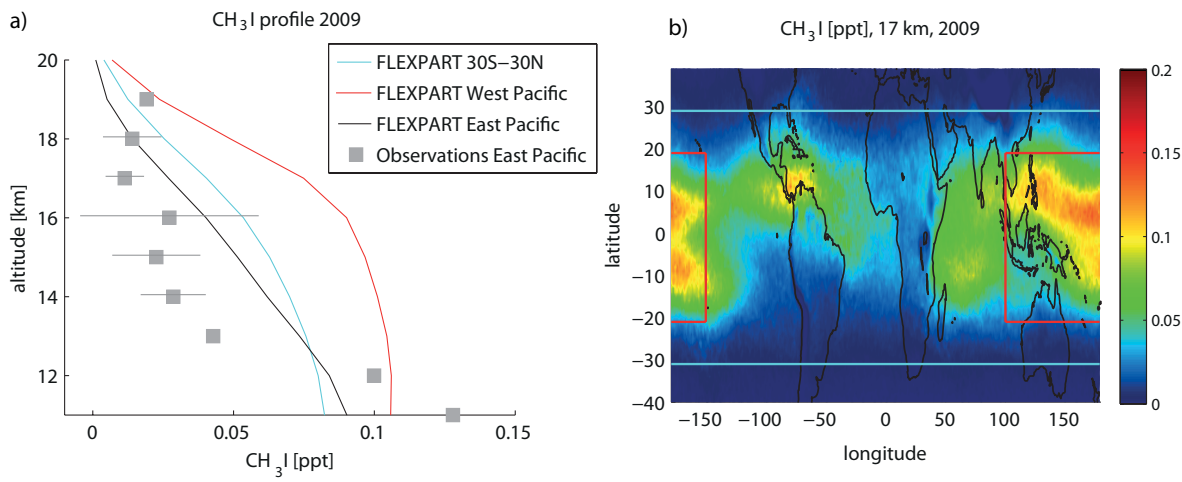

Fig. 10. Comparison between observed and modeled vertical profiles of $\mathrm{CH}_{3} \mathrm{I}$ in the upper troposphere and TTL (a). Observations are as in Fig. 7. Model output is averaged over the tropics (blue, $30^{\circ} \mathrm{S}-30^{\circ} \mathrm{N}$ ) and the western Pacific (red, $100^{\circ} \mathrm{W}-150^{\circ} \mathrm{E}, 20^{\circ} \mathrm{S}-20^{\circ} \mathrm{N}$ ) for 2009 and the eastern Pacific aircraft campaign region (green, $70-130^{\circ} \mathrm{E}, 6^{\circ} \mathrm{S}-30^{\circ} \mathrm{N}$ ) for the months of available measurements. Modeled tropical distribution of $\mathrm{CH}_{3} \mathrm{I}$ at $17 \mathrm{~km}$ for 2009 (b).

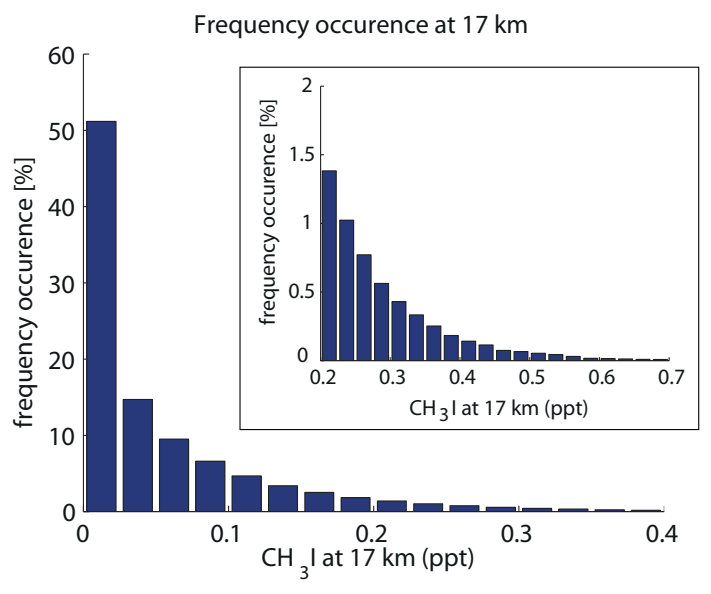

Fig. 11. Frequency occurrence of $\mathrm{CH}_{3} \mathrm{I}$ abundances at $17 \mathrm{~km}$ in the tropics for 2009 based on climatological emissions. The inset panel provides a zoom-in for the range of larger mixing ratios $0.2-0.7 \mathrm{ppt}$.

individual sections with high correlations between emission and vertical transport have been identified. The analysis of the meteorological conditions during the campaigns leads to the hypothesis that the horizontal surface winds act as a connecting link between emission and transport. On the one hand, horizontal wind strength directly determines the emission strength by diluting $\mathrm{CH}_{3} \mathrm{I}$ rich air and thereby controlling the uptake capacities of the atmosphere. Note that such mechanism works only for short-lived gases that are strongly supersaturated, as it is the case for $\mathrm{CH}_{3} \mathrm{I}$ in most regions. Elevated oceanic concentrations and larger concentration gradients between sea water and air in source regions support this effect. On the other hand, horizontal wind variations depend on the meteorological conditions, such as convective systems or storm events. In particular, strong horizontal winds associated with tropical cyclones (i.e., typhoons) can indicate efficient vertical uplift possibly penetrating the stratosphere and thereby complete the line of argument connecting $\mathrm{CH}_{3} \mathrm{I}$ emission strength and $\mathrm{CH}_{3} \mathrm{I}$ troposphere-stratosphere transport. Note that for the DRIVE campaign with very little uplift of $\mathrm{CH}_{3} \mathrm{I}$ into the upper TTL, emission and vertical transport are found to be uncorrelated. Determining the conditions that are required in order for the proposed mechanism to hold would require further analysis, ideally based on campaign data obtained during various meteorological situations.

The importance of the identified coincidences of strong emissions and efficient vertical transport for model simulations can be investigated with a simple test. For the campaign sections where a correlation between emission and transport was found, a considerable difference (of up to $70 \%$ ) would result when the transport simulations would have been initiated with one average emission instead of the highly variable emission time series. The opposite is true for campaign sections where emissions and vertical transport are uncorrelated. Here, model runs using one average emission lead to approximately the same amount of $\mathrm{CH}_{3} \mathrm{I}$ at the cold point level as model runs using the spatially resolved emissions. If such correlations, as identified for parts of the tropical campaigns, were a more general phenomena, than global modeling studies should be based on highly resolved emissions scenarios instead of uniform background mixing ratios. However, $\mathrm{CH}_{3} \mathrm{I}$ emission maps derived from observations can only be compiled in a climatological sense due to the low data density and cannot include information on the temporarily highly variable emission peaks. As a result, modeling studies based on climatological emission maps cannot fully take into account the simultaneous occurrence of large $\mathrm{CH}_{3} \mathrm{I}$ emissions and strong vertical uplift and might therefore lead to an underestimation of stratospheric $\mathrm{CH}_{3} \mathrm{I}$. Model simulations could benefit from using the climatological surface concentration maps in order to calculate the emissions instantaneously. Parameterizations of $\mathrm{CH}_{3} \mathrm{I}$ oceanic concentrations based on biogeochemical modeling (e.g., Stemmler et al., 2013) could help to further improve the modeling approach. 
Our results indicate that a realistic simulation of current and future iodine loading in the troposphere and stratosphere requires, among many other factors, highly resolved and well constrained $\mathrm{CH}_{3} \mathrm{I}$ emission scenarios. In particular, the simultaneous occurrence of large $\mathrm{CH}_{3} \mathrm{I}$ emissions and strong vertical uplift during the developing tropical typhoon suggest that future changes in tropical cyclone activity (Murakami et al., 2011) might influence the contribution of $\mathrm{CH}_{3} \mathrm{I}$ to stratospheric iodine in a changing climate.

Comparisons of aircraft measurements in the upper TTL with coincident model output give a good agreement with slightly larger $\mathrm{CH}_{3} \mathrm{I}$ abundances in the model. In the eastern Pacific region, where aircraft campaigns are available, the observations and the model indicate that around 0.01 to 0.02 ppt of $\mathrm{CH}_{3} \mathrm{I}$ enter the stratosphere. However, other tropical regions, which are subject to stronger convective activity, are suggested to have larger $\mathrm{CH}_{3} \mathrm{I}$ entrainment, e.g., $0.08 \mathrm{ppt}$ in the western Pacific. Note that our global climatological approach cannot account for any link between strong local emissions and vertical transport, which could lead to even larger entrainment, as discussed earlier. One example of such large entrainment is given by the peak emission and simultaneous strong vertical uplift during the SHIVA campaign, which results in a localized mixing ratio of $0.6 \mathrm{ppt}$, a magnitude larger than area-average mixing ratios. While our current understanding of the $\mathrm{CH}_{3} \mathrm{I}$ contribution to stratospheric iodine is mostly based on above-mentioned measurements and on model results (Aschmann et al., 2009; Ordóñez et al., 2012), which range around $0.01 \mathrm{ppt}$, our model results suggest an overall tropical contribution of $0.04 \mathrm{ppt}$. This is in good agreement with a model study from Donner et al. (2007), who derived similar $\mathrm{CH}_{3} \mathrm{I}$ mixing ratios at the cold point. Differences between existing model results can arise from different treatment of $\mathrm{CH}_{3} \mathrm{I}$ emissions, convection and photochemistry in the models. Note that in addition to our insufficient knowledge of the direct $\mathrm{CH}_{3} \mathrm{I}$ entrainment into the stratosphere, the atmospheric lifetime of inorganic iodine is a major uncertainty for the quantification of the stratospheric iodine budget. Our results show strong variations in the geographical distribution of $\mathrm{CH}_{3} \mathrm{I}$ entrainment, suggesting that currently available upper air measurements are not representative of global estimates. Further aircraft campaigns for different emission regions and especially for different convective transport regimes will be necessary in order to better understand the $\mathrm{CH}_{3} \mathrm{I}$ contribution to stratospheric iodine.

Acknowledgements. We thank the TransBrom, DRIVE and SHIVA team for collecting the samples and providing the oceanic VSLS measurements. The authors would also like to thank X. Zhu and L. Pope for their technical support in the analysis of the whole air samples, and R. Lueb, R. Hendershot, and S. Gabbard for support of the ATTREX and HIPPO airborne sample collections. We thank Ben Miller, Steve Montzka, and Fred Moore for contributing the $\mathrm{CH}_{3} \mathrm{I}$ measurements from the HIPPO2 aircraft campaign. The authors are grateful to the ECMWF for making the reanalysis product ERA-Interim available. This study is carried out within the WGL project TransBrom and the EU project SHIVA (FP7ENV-2007-1-226224) and contributes to the BMBF ROMIC grant THREAT 01LG1217A.

The service charges for this open access publication have been covered by a Research Centre of the Helmholtz Association.

Edited by: W. T. Sturges

\section{References}

Aschmann, J., Sinnhuber, B.-M., Atlas, E. L., and Schauffler, S. M.: Modeling the transport of very short-lived substances into the tropical upper troposphere and lower stratosphere, Atmos. Chem. Phys., 9, 9237-9247, doi:10.5194/acp-9-9237-2009, 2009.

Bange, H. W.: FS Poseidon cruise report P399 legs 2 and 3, IFMGEOMAR report no. 48 Rep. 48, 74 pp., IFM-GEOMAR, Kiel, 2011.

Bell, N., Hsu, L., Jacob, D. J., Schultz, M. G., Blake, D. R., Butler, J. H., King, D. B., Lobert, J. M., and Maier-Reimer, E.: Methyl iodide: Atmospheric budget and use as a tracer of marine convection in global models, J. Geophys. Res., 107, 4340, doi:10.1029/2001JD001151, 2002.

Bösch, H., Camy-Peyret, C., Chipperfield, M. P., Fitzenberger, R., Harder, H., Platt, U., and Pfeilsticker, K.: Upper limits of stratospheric IO and OIO inferred from center-to-limb-darkeningcorrected balloon-borne solar occultation visible spectra: Implications for total gaseous iodine and stratospheric ozone, J. Geophys. Res., 108, 4455, doi:10.1029/2002JD003078, D15, 2003.

Brasseur, G. and Solomon, S.: Aeronomy of the Middle Atmosphere, 2nd ed., Springer, New York, 2005.

Butler, J. H., King, D. B., Lobert, J. M., Montzka, S. A., YvonLewis, S. A., Hall, B. D., Warwick, N. J., Mondeel, D. J., Aydin, M., and Elkins, J. W.: Oceanic distributions and emissions of short-lived halocarbons, Global Biogeochem. Cy., 21, GB1023, doi:10.1029/2006GB002732, 2007.

Butz, A., Bösch, H., Camy-Peyret, C., Chipperfield, M. P., Dorf, M., Kreycy, S., Kritten, L., Prados-Román, C., Schwärzle, J., and Pfeilsticker, K.: Constraints on inorganic gaseous iodine in the tropical upper troposphere and stratosphere inferred from balloon-borne solar occultation observations, Atmos. Chem. Phys., 9, 7229-7242, doi:10.5194/acp-9-7229-2009, 2009.

Campos, M. L. A. M., Nightingale, P. D., and Jickells, T. D.: A comparison of methyl iodide emissions from seawater and wet depositional fluxes of iodine over the southern North Sea, Tellus B, 48, 106-114, doi:10.1034/j.1600-0889.1996.00010.x, 1996.

Carpenter, L. J., Archer S. D., and Beale, R.: Ocean-atmosphere trace gas exchange, Chem. Soc. Rev., 41, 6473-6506, 2012.

Carpenter, L. J., MacDonald, S. M., Shaw, M. D., Kumar, R., Saunders, R. W., Parthipan, R., Wilson, J., and Plane, J. M. C.: Atmospheric iodine levels influenced by sea surface emissions of inorganic iodine, Nature Geosci., 6, 108-111, doi:10.1038/ngeo1687, 2013.

Chameides, W. L. and Davis, D. D.: Iodine: Its possible role in tropospheric photochemistry, J. Geophys. Res., 85, 7383, doi:10.1029/JC085iC12p07383, 1980. 
Chang, C.-P., Harr, P. A., and Chen, H.-J.: Synoptic Disturbances over the Equatorial South China Sea and Western Maritime Continent during Boreal Winter, Mon. Weather Rev., 133, 489-503, doi:10.1175/MWR-2868.1, 2005.

Chipperfield, M. P.: New version of the TOMCAT/SLIMCAT offline chemical transport model: Intercomparison of stratospheric tracer experiments, Q. J. Roy. Meteorol. Soc., 132, 1179-1203, doi:10.1256/qj.05.51, 2006

Chuck, A. L., Turner, S. M., and Liss, P. S.: Oceanic distributions and air-sea fluxes of biogenic halocarbons in the open ocean, J. Geophys. Res., 110, C10022, doi:10.1029/2004JC002741, 2005.

Davis, D., Crawford, J., Liu, S., McKeen, S., Bandy, A., Thornton, D., Rowland, F., and Blake, D.: Potential impact of iodine on tropospheric levels of ozone and other critical oxidants, J. Geophys. Res., 101, 2135, doi:10.1029/95JD02727, 1996.

De Bruyn, W. J. and Saltzman, E. S.: Diffusivity of methyl bromide in water, Mar. Chem., 57, 55-59, 1997.

Dee, D. P., Uppala, S. M., Simmons, A. J., Berrisford, P., Poli, P., Kobayashi, S., Andrae, U., Balmaseda, M. A., Balsamo, G., Bauer, P., Bechtold, P., Beljaars, A. C. M., van de Berg, L., Bidlot, J., Bormann, N., Delsol, C., Dragani, R., Fuentes, M., Geer, A. J., Haimberger, L., Healy, S. B., Hersbach, H., Hólm, E. V., Isaksen, L., Kållberg, P., Köhler, M., Matricardi, M., McNally, A. P., Monge-Sanz, B. M., Morcrette, J.-J., Park, B.-K., Peubey, C., de Rosnay, P., Tavolato, C., Thépaut, J.-N. and Vitart, F., The ERA-Interim reanalysis: configuration and performance of the data assimilation system, Q. J. Roy. Meteorol. Soc., 137, 553597, 2011

Dix, B., Baidar, S., Bresch, J. F., Hall, S. R., Schmidt, K. S., Wang, S., and Volkamer, R.: Detection of iodine monoxide in the tropical free troposphere, P. Natl. Acad. Sci. USA, 110, 2035-2040, doi:10.1073/pnas.1212386110, 2013.

Donner, L. J., Horowitz, L. W., Fiore, A. M., Seman, C. J., Blake, D. R., and Blake, N. J.: Transport of radon-222 and methyl iodide by deep convection in the GFDL Global Atmospheric Model AM2, J. Geophys. Res., 112, D17303, doi:10.1029/2006JD007548, 2007.

Forster, C., Wandinger, U., Wotawa, G., James, P., Mattis, I., Althausen, D., Simmonds, P., O'Doherty, S., Jennings, S. G., Kleefeld, C., Schneider, J., Trickl, T., Kreipl, S., Jäger, H., and Stohl, A.: Transport of boreal forest fire emissions from Canada to Europe, J. Geophys. Res., 106, 22887, doi:10.1029/2001JD900115, 2001.

Forster, C., Stohl, A., and Seibert, P.: Parameterization of Convective Transport in a Lagrangian Particle Dispersion Model and Its Evaluation, J. Appl. Meteorol. Climatol., 46, 403-422, doi:10.1175/JAM2470.1, 2007.

Fueglistaler, S., Dessler, A. E., Dunkerton, T. J., Folkins, I., Fu, Q., and Mote, P. W.: Tropical tropopause layer, Rev. Geophys., 47, RG1004, doi:10.1029/2008RG000267, 2009.

Fuhlbrügge, S., Krüger, K., Quack, B., Atlas, E., Hepach, H., and Ziska, F.: Impact of the marine atmospheric boundary layer conditions on VSLS abundances in the eastern tropical and subtropical North Atlantic Ocean, Atmos. Chem. Phys., 13, 6345-6357, doi:10.5194/acp-13-6345-2013, 2013.

Gettelman, A., Lauritzen, P. H., Park, M., and Kay, J. E.: Processes regulating short-lived species in the tropical tropopause layer, J. Geophys. Res., 114, D1330, doi:10.1029/2009JD011785, 2009.
Happell, J. D. and Wallace, D. W. R.: Methyl iodide in the Greenland/Norwegian Seas and the tropical Atlantic Ocean: Evidence for photochemical production, Geophys. Res. Lett., 23, 21052108, doi:10.1029/96GL01764, 1996.

Hossaini, R., Chipperfield, M. P., Feng, W., Breider, T. J., Atlas, E., Montzka, S. A., Miller, B. R., Moore, F., and Elkins, J.: The contribution of natural and anthropogenic very short-lived species to stratospheric bromine, Atmos. Chem. Phys., 12, 371380, doi:10.5194/acp-12-371-2012, 2012.

Hughes, C., Franklin, D. J., and Malin, G.: Iodomethane production by two important marine cyanobacteria: Prochlorococcus marinus (CCMP 2389) and Synechococcus sp. (CCMP 2370), Marine Chem., 125, 19-25, doi:10.1016/j.marchem.2011.01.007, 2011.

Jones, C. E., Hornsby, K. E., Sommariva, R., Dunk, R. M., von Glasow, R., McFiggans, G., and Carpenter, L. J.: Quantifying the contribution of marine organic gases to atmospheric iodine, Geophys. Res. Lett., 37, L18804, doi:10.1029/2010GL043990, 2010.

Krüger, K. and Quack, B.: Introduction to special issue: the TransBrom Sonne expedition in the tropical West Pacific, Atmos. Chem. Phys., 13, 9439-9446, doi:10.5194/acp-13-9439-2013, 2013.

Krüger, K., Tegtmeier, S., and Rex, M.: Variability of residence time in the Tropical Tropopause Layer during Northern Hemisphere winter, Atmos. Chem. Phys., 9, 6717-6725, doi:10.5194/acp-96717-2009, 2009.

Levine, J. G., Braesicke, P., Harris, N. R. P., Savage, N. H., and Pyle, J. A.: Pathways and timescales for troposphere-to-stratosphere transport via the tropical tropopause layer and their relevance for very short lived substances, J. Geophys. Res., 112, D04308, doi:10.1029/2005JD006940, 2007.

Liss, P. S. and Slater, P. G.: Flux of Gases across the Air-Sea Interface, Nature, 247, 181-184, doi:10.1038/247181a0, 1974.

Mahajan, A. S., Plane, J. M. C., Oetjen, H., Mendes, L., Saunders, R. W., Saiz-Lopez, A., Jones, C. E., Carpenter, L. J., and McFiggans, G. B.: Measurement and modelling of tropospheric reactive halogen species over the tropical Atlantic Ocean, Atmos. Chem. Phys., 10, 4611-4624, doi:10.5194/acp-10-4611-2010, 2010.

Manley, S. L. and Dastoor, M. N.: Methyl halide production from the giant kelp, Macrocystis and estimates of global CH3X production by kelp, Limnol. Oceanogr., 32, 709-715, 1987.

Manley, S. L. and Dastoor, M. N.: Methyl iodide (CH3I) production by kelp and associated microbes, Marine Biol., 98, 477-482, doi:10.1007/BF00391538, 1988.

Manley, S. L. and De la Cuesta, J. L.: Methyl iodide production from marine phytoplankton cultures, Limnol. Oceanogr., 41, 142-147, 1997.

McFiggans, G., Plane, J. M. C., Allan, B. J., Carpenter, L. J., Coe, H., and O'Dowd, C.: A modeling study of iodine chemistry in the marine boundary layer, J. Geophys. Res., 105, 14371, doi:10.1029/1999JD901187, 2000.

McNeil, C. L. and D'Asaro, E. A.: Parameterization of air-sea gas fluxes at extreme wind speeds, J. Mar. Syst., 66, 110-121, 2007.

Montzka, S. A. and Reimann, S.: Ozone-depleting substances and related chemicals, in Scientific Assessment of Ozone Depletion: 2010, Global Ozone Research and Monitoring Project - Report No. 52, Geneva, Switzerland, 2011.

Moore, R. M. and Groszko, W.: Methyl iodide distribution in the ocean and fluxes to the atmosphere, J. Geophys. Res., 104, 11163, doi:10.1029/1998JC900073, 1999. 
Moore, R. M. and Zafiriou, O. C.: Photochemical production of methyl iodide in seawater, J. Geophys. Res., 99, 16415, doi:10.1029/94JD00786, 1994.

Moore, R. M., Geen, C. E., and Tait, V. K.: Determination of Henry's Law constants for a suite of naturally occurring halogenated methanes in seawater, Chemosphere, 30, 1183-1191, doi:10.1016/0045-6535(95)00009-W, 1995.

Murakami, H., Wang, B., and Kitoh, A.: Future Change of Western North Pacific Typhoons: Projections by a $20-\mathrm{km}-$ Mesh Global Atmospheric Model*, J. Climate, 24, 1154-1169, doi:10.1175/2010JCLI3723.1, 2011.

Nightingale, P. D., Malin, G., Law, C. S., Watson, A. J., Liss, P. S., Liddicoat, M. I., Boutin, J., and Upstill-Goddard, R. C.: In situ evaluation of air-sea gas exchange parameterizations using novel conservative and volatile tracers, Global Biogeochem. Cy., 14(1), 373-387, doi:10.1029/1999GB900091, 2000.

Ordóñez, C., Lamarque, J.-F., Tilmes, S., Kinnison, D. E., Atlas, E. L., Blake, D. R., Sousa Santos, G., Brasseur, G., and Saiz-Lopez, A.: Bromine and iodine chemistry in a global chemistry-climate model: description and evaluation of very short-lived oceanic sources, Atmos. Chem. Phys., 12, 1423-1447, doi:10.5194/acp12-1423-2012, 2012.

O’Dowd, C. D., Jimenez, J. L., Bahreini, R., Flagan, R. C., Seinfeld, J. H., Hämeri, K., Pirjola, L., Kulmala, M., Jennings, S. G., and Hoffmann, T.: Marine aerosol formation from biogenic iodine emissions, Nature, 417, 632-636, 2002.

Puentedura, O., Gil, M., Saiz-Lopez, A., Hay, T., Navarro-Comas, M., Gómez-Pelaez, A., Cuevas, E., Iglesias, J., and Gomez, L.: Iodine monoxide in the north subtropical free troposphere, Atmos. Chem. Phys., 12, 4909-4921, doi:10.5194/acp-12-49092012, 2012.

Pundt, I., Pommereau, J. P., Phillips, C., and Lateltin, E.: Upper limits of iodine oxide in the lower stratosphere, J. Atmos. Chem., 30, 173-185, 1998.

Quack, B. und Krüger, K. (Eds.): RV SONNE Fahrtbericht/Cruise Report SO218 SHIVA 15.-29.11.2011 Singapore - Manila, Philippines Stratospheric Ozone: Halogens in a Varying Atmosphere Part 1: SO218 - SHIVA Summary Report (in German) Part 2: SO218 - SHIVA English reports of participating groups GEOMAR Report, N. Ser. 012, GEOMAR Helmholtz-Zentrum für Ozeanforschung, Kiel, Germany, 112 pp., doi:10.3289/GEOMAR_REP_NS_12_2013 (http://oceanrep.geomar.de/22284/), 2013.

Quack, B., Atlas, E., Petrick, G., Stroud, V., Schauffler, S., and Wallace, D. W. R.: Oceanic bromoform sources for the tropical atmosphere, Geophys. Res. Lett., 31, L23S05, doi:10.1029/2004GL020597, 2004.

Quack, B., Atlas, E., Krüger, K., Taylor, B., Dinter, T., Bracher, A., Petrick, G., Stange, K., Fuhlbrügge, S., Tegtmeier, S., Wache, S., and Wallace, D.: Distribution and air-sea fluxes of halocarbons through the Western Pacific, Atmos. Chem. Phys. Discuss., in preparation, 2013.

Rasmussen, R. A., Khalil, M. A. K., Gunawardena, R., and Hoyt, S. D.: Atmospheric methyl iodide $\left(\mathrm{CH}_{3} \mathrm{I}\right)$, J. Geophys. Res., 87, 3086, doi:10.1029/JC087iC04p03086, 1982.

Redeker, K. R., Wang, N.-Y., Low, J. C., McMillan, A., Tyler, S. C., and Cicerone, R. J.: Emissions of Methyl Halides and Methane from Rice Paddies, Science, 290, 966-969, doi:10.1126/science.290.5493.966, 2000.
Richter, U. and Wallace, D. W. R.: Production of methyl iodide in the tropical Atlantic Ocean, Geophys. Res. Lett., 31, L23S03, doi:10.1029/2004GL020779, 2004.

Romps, D. M. and Kuang, Z.: Overshooting convection in tropical cyclones, Geophys. Res. Lett., 36, L09804, doi:10.1029/2009GL037396, 2009.

Rossow, W. B. and Pearl, C.: 22-Year survey of tropical convection penetrating into the lower stratosphere, Geophys. Res. Lett., 34, L04803, doi:10.1029/2006GL028635, 2007.

Saiz-Lopez, A., Plane, J. M. C., Baker, A. R., Carpenter, L. J., Von Glasow, R., Martín, J. C. G., McFiggans, G. and Saunders, R. W.: Atmospheric chemistry of iodine, Chem. Rev., 112, 1773804, doi:10.1021/cr200029u, 2012.

Sander, S., Friedl, R., Barker, J., Golden, D., Kurylo, M., Wine, P., Abbatt, J., Burkholder, J., Kolb, C., Moortgat, G., Huie, R., V. L. Orkin, "Chemical Kinetics and Photochemical Data for Use in Atmospheric Studies, Evaluation No. 17”, JPL Publication 10-6, Jet Propulsion Laboratory, Pasadena, 2011.

Singh, H. B., Salas, L. J., and Stiles, R. E.: Methyl halides in and over the eastern Pacific $\left(40^{\circ} \mathrm{N}-32^{\circ} \mathrm{S}\right)$, J. Geophys. Res., 88, 3684, doi:10.1029/JC088iC06p03684, 1983.

Sive, B. C., Varner, R. K., Mao, H., Blake, D. R., Wingenter, O. W., and Talbot, R.: A large terrestrial source of methyl iodide, Geophys. Res. Lett., 34, L17808, doi:10.1029/2007GL030528, 2007.

Smythe-Wright, D., Boswell, S. M., Breithaupt, P., Davidson, R. D., Dimmer, C. H., and Eiras Diaz, L. B.: Methyl iodide production in the ocean: Implications for climate change, Global Biogeochem. Cy., 20, GB3003, doi:10.1029/2005GB002642, 2006.

Solomon, S., Garcia, R. R., and Ravishankara, A. R.: On the role of iodine in ozone depletion, J. Geophys. Res., 99, 20491, doi:10.1029/94JD02028, 1994.

Spichtinger, N., Wenig, M., James, P., Wagner, T., Platt, U., and Stohl, A.: Satellite detection of a continental-scale plume of nitrogen oxides from boreal forest fires, Geophys. Res. Lett., 28, 4579-4582, doi:10.1029/2001GL013484, 2001.

Stemmler, I., Rothe, M., Hense, I., and Hepach, H.: Numerical modelling of methyl iodide in the eastern tropical Atlantic, Biogeosciences, 10, 4211-4225, doi:10.5194/bg-10-4211-2013, 2013.

Stohl, A. and Thomson, D. J.: A density correction for Lagrangian particle dispersion models, Boundary-Lay. Meteorol., 90, 155167, doi:10.1023/A:1001741110696, 1999.

Stohl, A. and Trickl, T.: A textbook example of long-range transport: Simultaneous observation of ozone maxima of stratospheric and North American origin in the free troposphere over Europe, J. Geophys. Res., 104, 30445, doi:10.1029/1999JD900803, 1999.

Stohl, A., Hittenberger, M., and Wotawa, G.: Validation of the lagrangian particle dispersion model FLEXPART against largescale tracer experiment data, Atmos. Environ., 32, 4245-4264, doi:10.1016/S1352-2310(98)00184-8, 1998.

Stohl, A., Forster, C., Frank, A., Seibert, P., and Wotawa, G.: Technical note: The Lagrangian particle dispersion model FLEXPART version 6.2, Atmos. Chem. Phys., 5, 2461-2474, doi:10.5194/acp-5-2461-2005, 2005.

Tegtmeier, S., Krüger, K., Quack, B., Atlas, E. L., Pisso, I., Stohl, A., and Yang, X.: Emission and transport of bromocarbons: from the West Pacific ocean into the stratosphere, Atmos. Chem. Phys., 12, 10633-10648, doi:10.5194/acp-12-10633-2012, 2012. 
Toon, O. B., Starr, D. O., Jensen, E. J., Newman, P. A., Platnick, S., Schoeberl, M. R., Wennberg, P. O., Wofsy, S. C., Kurylo, M. J., Maring, H., Jucks, K. W., Craig, M. S., Vasques, M. F., Pfister, L., Rosenlof, K. H., Selkirk, H. B., Colarco, P. R., Kawa, S. R., Mace, G. G., Minnis, P., and Pickering, K. E.: Planning, implementation, and first results of the Tropical Composition, Cloud and Climate Coupling Experiment (TC4), J. Geophys. Res., 115, D00J04, doi:10.1029/2009JD013073, 2010.

Vogt, R., Sander, R., Von Glasow, R., and Crutzen, P. J.: Iodine Chemistry and its Role in Halogen Activation and Ozone Loss in the Marine Boundary Layer?: A Model Study, J. Atmos. Chem., 32, 375-395, 1999.

Wanninkhof, R.: Relationship between wind speed and gas exchange over the ocean, J. Geophys. Res., 97, 7373-7382, 1992.

Wennberg, P. O., Brault, J. W., Hanisco, T. F., Salawitch, R. J., and Mount, G. H.: The atmospheric column abundance of IO: Implications for stratospheric ozone, J. Geophys. Res., 102, 88878898, doi:10.1029/96JD03712, 1997.

Wilke, C. R. and Chang, P.: Correlation of diffusion coefficients in dilute solutions, AIChE (Am. Inst. Chem. Eng.) J., 1, 264-270, 1955.

WMO (World Meteorological Organization): Scientific Assessment of Ozone Depletion: 2006, Global Ozone Research and Monitoring Project - Report No. 50, Geneva., 2007.

Wofsy, S. C., HIPPO Sci Team, Cooperating Modellers Team and Satellite Team: HIAPER Pole-to-Pole Observations (HIPPO): fine-grained, global-scale measurements of climatically important atmospheric gases and aerosols., Philosophical Transactions Series A, Mathematical, physical, and engineering sciences, 369, 2073-2086, doi:10.1098/rsta.2010.0313, 2011.
Yokouchi, Y., Osada, K., Wada, M., Hasebe, F., Agama, M., Murakami, R., Mukai, H., Nojiri, Y., Inuzuka, Y., Toom-Sauntry, D., and Fraser, P.: Global distribution and seasonal concentration change of methyl iodide in the atmosphere, J. Geophys. Res., 113, D18311, doi:10.1029/2008JD009861, 2008.

Zhou, Y., Mao, H., Russo, R. S., Blake, D. R., Wingenter, O. W., Haase, K. B., Ambrose, J., Varner, R. K., Talbot, R., and Sive, B. C.: Bromoform and dibromomethane measurements in the seacoast region of New Hampshire, 2002-2004, J. Geophys. Res., 113, D08305, doi:10.1029/2007JD009103, 2008.

Ziska, F., Quack, B., Abrahamsson, K., Archer, S. D., Atlas, E., Bell, T., Butler, J. H., Carpenter, L. J., Jones, C. E., Harris, N. R. P., Hepach, H., Heumann, K. G., Hughes, C., Kuss, J., Krüger, K., Liss, P., Moore, R. M., Orlikowska, A., Raimund, S., Reeves, C. E., Reifenhäuser, W., Robinson, A. D., Schall, C., Tanhua, T., Tegtmeier, S., Turner, S., Wang, L., Wallace, D., Williams, J., Yamamoto, H., Yvon-Lewis, S., and Yokouchi, Y.: Global sea-toair flux climatology for bromoform, dibromomethane and methyl iodide, Atmos. Chem. Phys., 13, 8915-8934, doi:10.5194/acp13-8915-2013, 2013. 